\title{
Trinucleotide repeats in the human androgen receptor: a molecular basis for disease
}

\section{S Choong ${ }^{1}$ and E M Wilson ${ }^{2}$}

\author{
${ }^{1}$ Department of Pediatric Endocrinology, Mater Misericordiae Children's Hospital, South Brisbane, \\ Queensland 4101, Australia \\ ${ }^{2}$ The Laboratories for Reproductive Biology and the Departments of Pediatrics and Biochemistry and \\ Biophysics, University of North Carolina, Chapel Hill, North Carolina 27599-7500, USA
}

(Requests for offprints should be addressed to E M Wilson)

\section{THE ANDROGEN RECEPTOR}

\section{Sequence similarities among the steroid receptor family of nuclear receptors}

The androgen receptor (AR) is a member of the superfamily of nuclear hormone receptors (Zhou et al. 1994). This family of ligand-dependent transcription factors are key regulatory proteins in diverse physiological processes, including embryogenesis, development and homeostasis. Steroids are lipophilic hormones derived from hydroxylation and side chain cleavage of cholesterol. Current theory suggests that steroids diffuse through cell membranes to interact with their cognate receptors, although recent data suggests a transport role of the serum binding proteins (Rosner 1991). Upon binding hormone, steroid receptors undergo allosteric changes which enable them to bind high affinity sites in chromatin and modulate gene expression (Yamamoto 1985) (Fig. 1). Cloning of the cDNAs of the glucocorticoid (Hollenberg et al. 1985), oestrogen (Green et al. 1986), mineralocorticoid (Arriza et al. 1987) and progesterone (Misrahi et al. 1987) receptors revealed structural homology in three functional domains; a highly conserved DNA binding domain, a steroid binding domain, and an amino- or $\mathrm{NH}_{2}$-terminal domain that is important for transcriptional activity (Evans 1988, Mangelsdorf et al. 1995).

\section{Functional domains of AR}

The human AR gene localizes to the $\mathrm{X}$ chromosome at Xq11-12 (Brown et al. 1989) and is encoded in 8 exons (Lubahn et al. 1988b). The calculated molecular weight of AR is 98999 Daltons (Da). The major AR mRNA species is about 10 kilobases $(\mathrm{kb})$ with a less abundant mRNA of $7 \mathrm{~kb}$ detected in some human tissues (Lubahn et al. 1988a). Differences in the published AR cDNA sequence relate primarily to two polymorphic trinucleotide repeats encoding polyglutamine and polyglycine within the first exon (Chang et al. 1988a, Lubahn et al. 1988b, Tilley et al. 1989). Functional organization of AR is similar to that of the other members of the steroid receptor family (Lubahn et al. 1988a, Kuiper et al. 1989, Rundlett et al. 1990, Jenster et al. 1991, Zhou et al. 1994). The entire amino-terminal domain is encoded by the first exon, the two zinc fingers of the DNA binding domain by exons 2 and 3 , the hinge region which contains the nuclear targeting signal by part of exon 4 , and the steroid binding domain by exons 4-8 (Fig. 2). Amino acid sequence homology with other members of the steroid receptor family is greatest in the DNA binding domain.

\section{Role of the androgen receptor in virilization}

In the $46 \mathrm{XY}$ human embryo, differentiation of the testes occurs at approximately six weeks in the presence of testis determining factor which is encoded by a gene residing in the sex determining region of the short arm of the $\mathrm{Y}$ chromosome (Sinclair et al. 1990). The reproductive tissues undergo virilization in the presence of testosterone and $5 \alpha$-dihydrotestosterone in an ordered sequence. Production of Müllerian inhibitory factor by the testis induces regression of the Müllerian ducts (Jost et al. 1973). During puberty further androgenization occurs with the rise in serum testosterone (Moorandian et al. 1987). The critical 


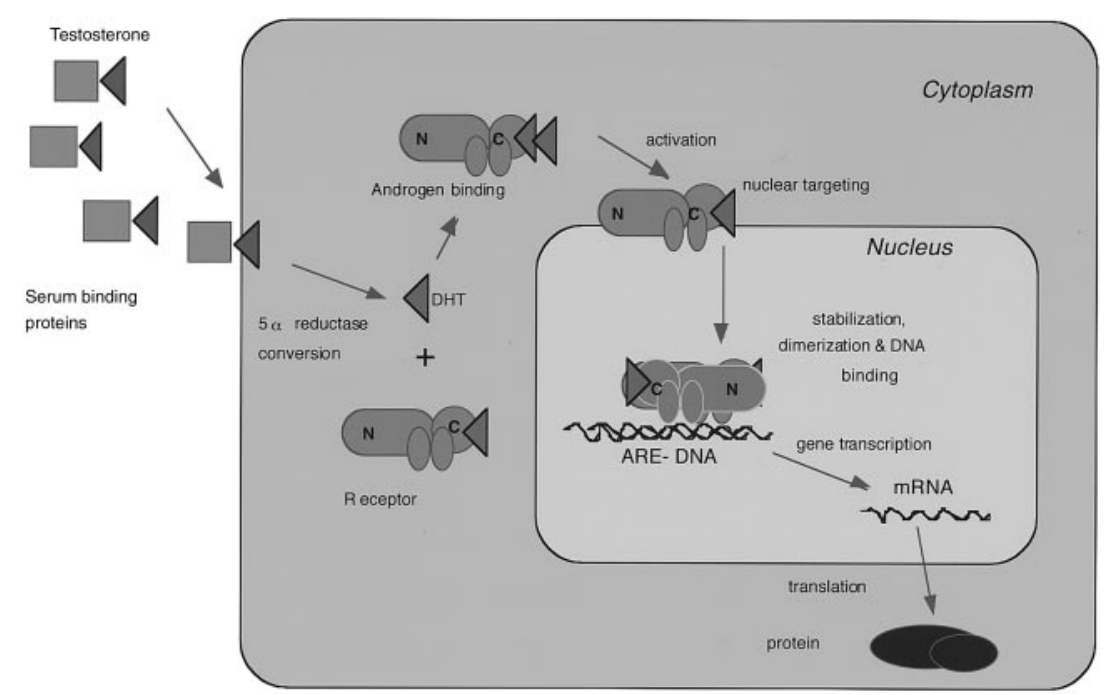

FIGURE 1. Schematic diagram of the events in androgen action.

Testosterone is transported to the cell by serum binding proteins, diffuses through the plasma membrane and binds to the androgen receptor (AR). $5 \alpha$-Reductase converts testosterone to $5 \alpha$-dihydrotestosterone (DHT) in some target cells. Upon binding testosterone or DHT in the carboxyl-terminal steroid binding domain (C), AR undergoes conformational changes involving an $\mathrm{NH}_{2}$-/carboxyl-terminal interaction and receptor stabilization. Activation of the nuclear targeting signal localizes AR to the nucleus where dimerization and DNA binding to cis acting regulatory androgen response elements (ARE-DNA) effects gene transcription.

$\mathrm{N}$ denotes the AR amino-terminus.

role of AR in male sexual differentiation is now clearly established by the study of naturally occurring mutations in the AR gene of patients with androgen insensitivity syndrome and has been the subject of a number of recent reviews (McPhaul et al. 1993, Sultan et al. 1993, Patterson et al. 1994, Brown 1995, Quigley et al. 1995, Gottlieb et al. 1997).

There are now over 200 reported mutations of the human AR gene identified in patients with androgen insensitivity syndrome and somatic mutations in

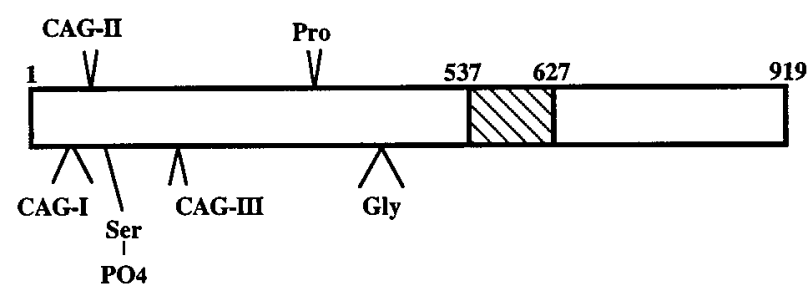

FIGURE 2. Schematic diagram of the AR coding sequence with trinucleotide repeat regions (CAG coding for glutamine), the DNA binding domain (hatched area) and serine 94 phosphorylation site indicated in the 919 amino acid residue human AR. prostatic cancer tissue (Gottlieb et al. 1997). With few exceptions the mutations in the human AR gene associated with androgen insensitivity are limited to the DNA and steroid binding domains and splice site mutations. The distribution is uneven through these domains and there is an increase in density of mutations in exons 5 and 7 (McPhaul et al. 1993, Quigley et al. 1995). Notably these two exons represent the most highly conserved regions of AR when compared with other members of the steroid receptor subfamily and may contain critical structural elements of the ligand binding pocket. The functional characterization of $\mathrm{AR}$ mutations have defined specific regions of the receptor involved in ligand activation and binding and receptor dimerization. Important areas for further investigation include the effect of steroid binding domain mutations on the recently described receptor coactivator association (Yeh \& Chang 1996).

Within the amino-terminal domain comparatively few mutations associated with androgen insensitivity have been reported. Examples include premature stop codons (Zoppi et al. 1993), frame shifts (Batch et al. 1992, Hiort et al. 1994), missense mutations (Gottlieb et al. 1997) and expansions of 
TABLE 1. Triplet length of the major trinucleotide repeats

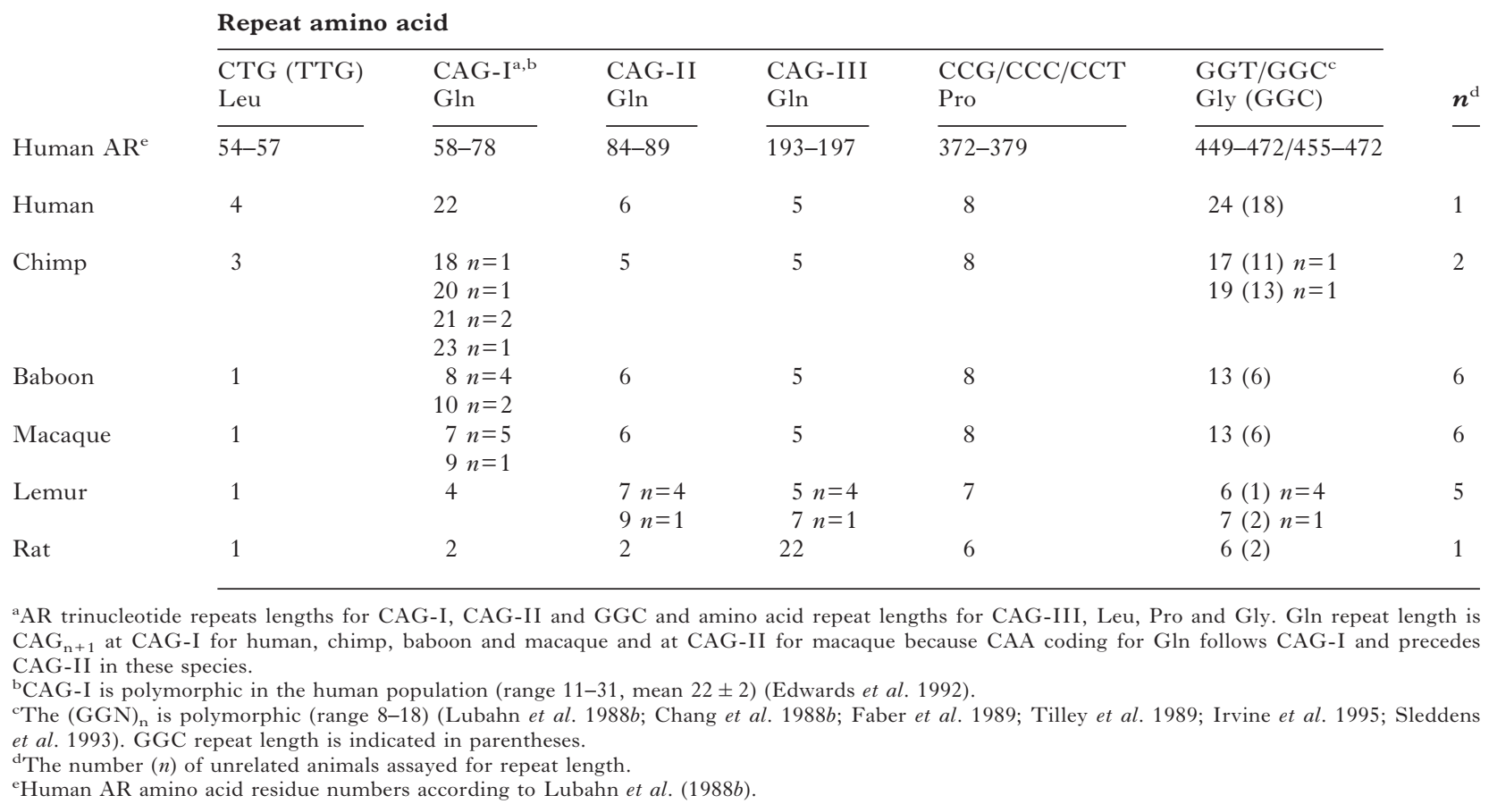

the homopolymeric CAG trinucleotide repeat (La Spada et al. 1991). This was initially thought to be due to the lower sensitivity of screening techniques such as denaturing gradient gel electrophoresis in the presence of the high GC content of the amino-terminus. However our recent findings of greater sequence divergence within the aminoterminal domain between primates compared with the DNA and steroid binding domains suggests that the amino-terminal domain may be more functionally tolerant to amino acid substitution than either the DNA or steroid binding domains. Thus naturally occurring mutations within the aminoterminus of AR may be less likely to present with an androgen insensitive phenotype.

\section{Evolution of the primate androgen receptor trinucleotide repeats}

We undertook sequence analysis of the AR DNA in several primate species to investigate the evolution and functional consequences of polymorphic variation within the AR. AR nucleotide and amino acid sequence were compared among the primates, including the most primitive prosimian lemur. The amino-terminal CAG repeat whose expansion is associated with spinal and bulbar muscular atrophy (SBMA) (see below) decreases exponentially among the primate species with increasing evolutionary distance from human (Table 1). A less polymorphic GGC repeat together with the preceding $\left(\mathrm{GGT}_{3} \mathrm{GGG}(\mathrm{GGT})_{2}\right.$ sequence code for 24 consecutive glycine residues in human AR. Like the $\mathrm{CAG}$ repeat, the $\mathrm{GGC}$ repeat shortens inversely and exponentially among primates with increasing evolutionary distance from human, undergoing concurrent GGC and GGG transition to GGT as the GGC repeat expands (Choong et al. 1998). However, in contrast to the CAG repeat whose expansion influenced AR mRNA levels (Choong et al. 1996a), the shorter GGC repeats in lower primates did not appear to alter AR mRNA expression. The amino-terminal 1-53 and 360-429 amino acid residues in human AR are completely conserved among the primate species studied. As these regions have not been found critical for AR transactivation (Zhou et al. 1993), their high conservation may reflect the complete sequence conservation of the steroid binding domain among the primates, as we demonstrated previously that these $\mathrm{NH}_{2}$-terminal regions interact with the androgen-bound AR steroid binding domain during AR dimerization (Langley et al. 1995). Overall, however, exon A coding for the $\mathrm{NH}_{2}$-terminal region and exon $\mathrm{D}$ coding for the hinge region show the greatest divergence of amino acid sequence whereas exons $\mathrm{G}$ and $\mathrm{H}$ in the steroid binding domain are the most highly conserved (Table 2). 


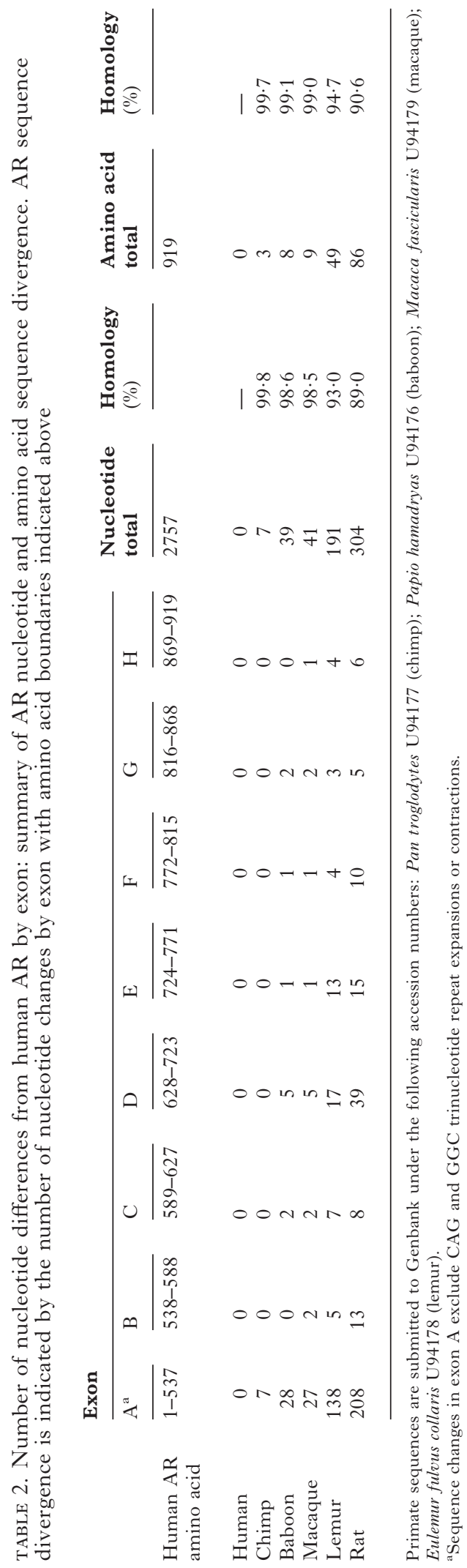


The CAG and GGC repeats expanded predominantly after branching of the old world monkeys. These mutations support the time of diversification among the most primitive primates and comparison of lemur AR DNA sequence with that of rat and higher primates supports their transitional status among evolving primates.

\section{OVERVIEW OF THE TRINUCLEOTIDE REPEATS AND NEURODEGENERATIVE DISEASES}

The human genome contains arrays of tandem nucleotide repeats, the length of which may be polymorphic across the population (Craig-Holmes \& Shaw 1971, Weber 1990, Karlin \& Burge 1996). Trinucleotide repeat sequences are characterized by their ability to undergo dynamic mutation or nucleotide alteration over a compressed time span of only a few generations. Products of dynamic trinucleotide mutations may diverge further from the original DNA on a subsequent meiosis, with the probability of mutation being directly related to the number of repeating units (Sutherland \& Richards 1995). Proposed mechanisms contributing to nucleotide repeat instability include trans-acting factors such as DNA enzymes involved in replication and repair (Strand et al. 1993, Jaworski et al. 1995). Linkage analyses of flanking markers suggest that cis acting DNA elements within the vicinity of tandem repeats contribute to instability - the founder effect (Kunst \& Warren 1994, Richards et al. 1996).

In order to investigate a founder effect, Rubinsztein et al. (1995c) examined a $\Delta 2642$ deletion of four consecutive codons within the Huntington's disease gene in a range of human and non-human primate populations. The $\Delta 2642$ deletion was associated with human chromosomes containing 20 or more CAG repeats, suggesting that expanded repeat sequences increase and result in the overrepresentation of the $\Delta 2642$ deletion on Huntington's disease chromosomes (Rubinsztein et al. 1995c).

Uninterrupted perfect repeats are themselves inherently unstable (Sutherland \& Richards 1993) and probably exert powerful cis acting destabilizing effects on DNA repeat sequences. One mechanistic model that has been proposed to explain nucleotide repeat expansion postulates that pausing and slippage of the elongated strand may occur during polymerization, resulting in deletion or addition of tandem repeats (Richards \& Sutherland 1994, Kang et al. 1995a,b). In long repeats two breaks may occur during polymerization, resulting in a frag- ment consisting solely of tandem repeats with the ability to slide during polymerization thus facilitating the addition of additional copies of the repeat to the original sequence (Richards \& Sutherland 1994).

The phenomenon of a dynamic mutation was first reported in association with an hereditary neurological disorder, the fragile $\mathrm{X}$ syndrome, which is a form of familial X-linked mental retardation (Kremer et al. 1991). Discovery of AR containing an expanded polymorphic CAG trinucleotide repeat as the candidate gene for X-linked spinal and bulbar muscular atrophy (La Spada et al. 1991) heralded the subsequent identification of trinucleotide expansions in association with a heterogeneous group of neurodegenerative disorders including most notably Huntington's disease (Anonymous 1993). Thirteen neurodegenerative diseases associated with tandem repeat mutations have now been identified (Tables 3 and 4) and more will probably be discovered. These mutations can be broadly classed into two groups: repeat expansions located within noncoding regions of the gene and CAG trinucleotide repeat expansions within protein coding regions that result in a polyglutamine tract.

\section{CAG TRIPLET REPEATS AND DISEASE}

The group of disorders associated with CAG trinucleotide repeat expansions constitute a clinically heterogeneous cluster of neurodegenerative diseases with a phenotypic spectrum that includes progressive muscular atrophy and androgen insensitivity in SBMA (La Spada et al. 1992), dementia and choreoathetosis in Huntington's disease (Kremer et al. 1994), ataxia, opthalmoparesis and weakness in the autosomal dominant spinocerebellar ataxias (Harding 1993), cerebellar ataxia, myoclonic epilepsy and dementia in Dentato-rubropallidoluysian atrophy (Miwa 1994), and generalized epilepsy without myoclonus and schizophrenia in the Haw River syndrome (Burke et al. 1994). The latter two conditions share the identical causative mutation and the basis for phenotypic differences between the two syndromes remains unresolved (Table 4).

Significant differences exist among the causative genes of CAG-related diseases, including chromosomal location and predicted normal function and the neuroanatomic and subcellular localization of the gene products. With the exception of X-linked SBMA, all share the autosomal dominant mode of inheritance. Features common to all these disorders are anticipation on paternal transmission and translation of the CAG repeat sequence to form the polyglutamine repeat within the protein (Table 4). 

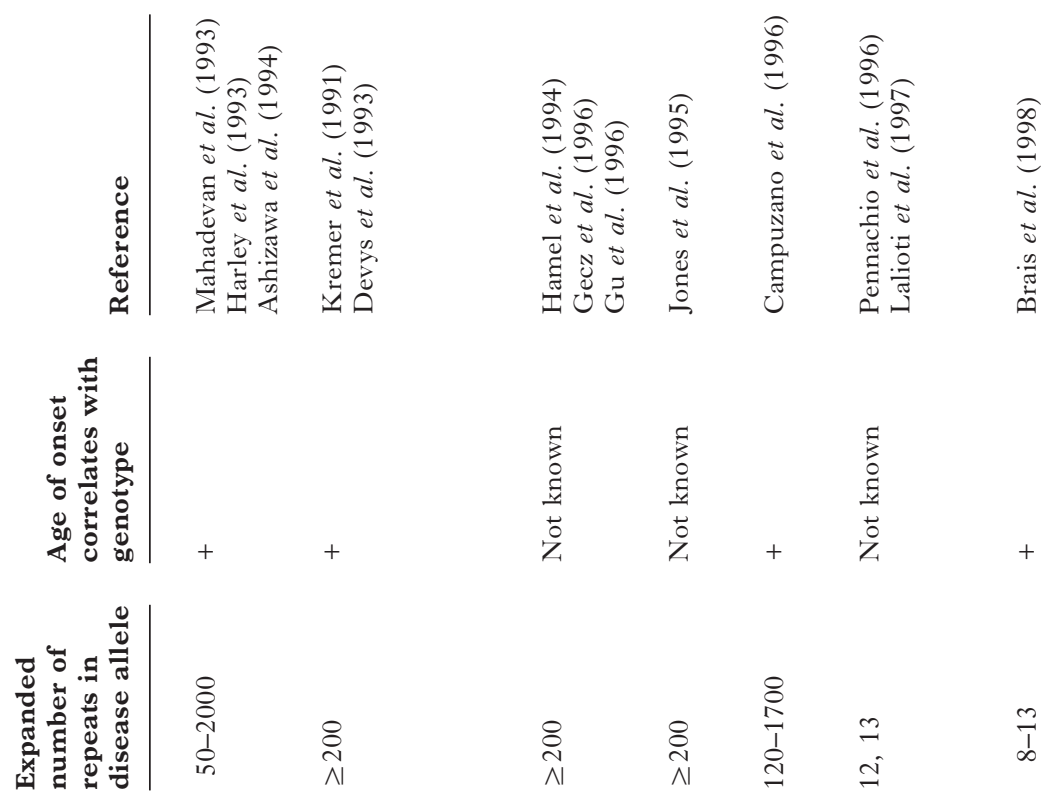

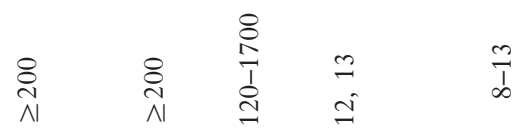

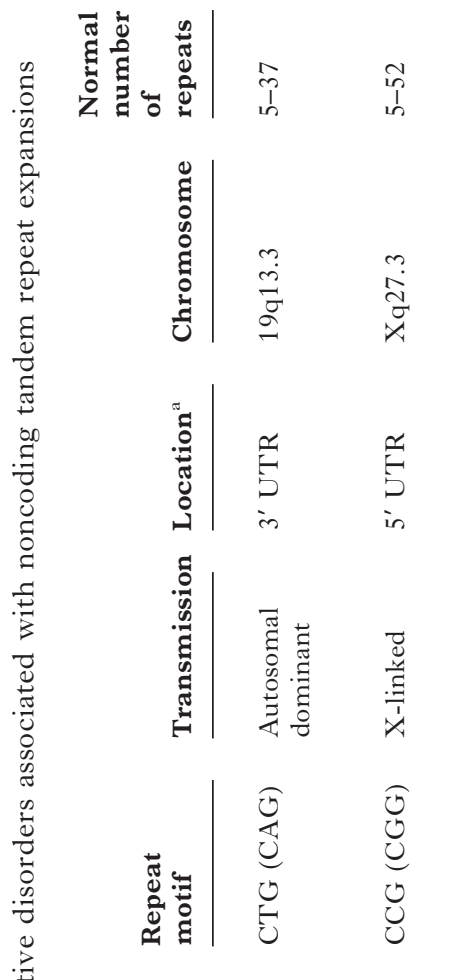

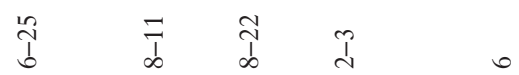

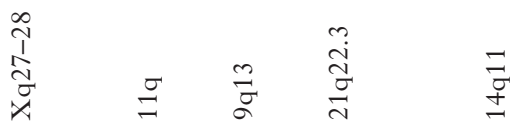

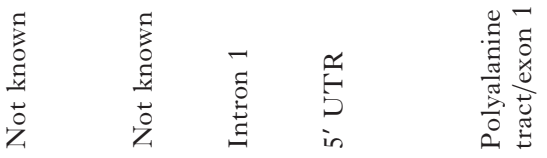

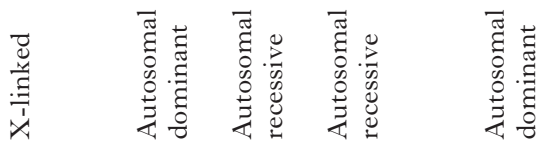

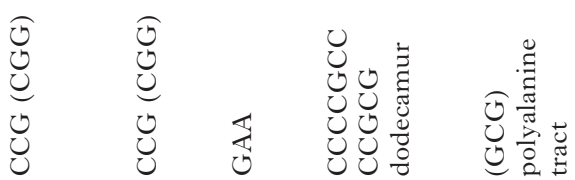
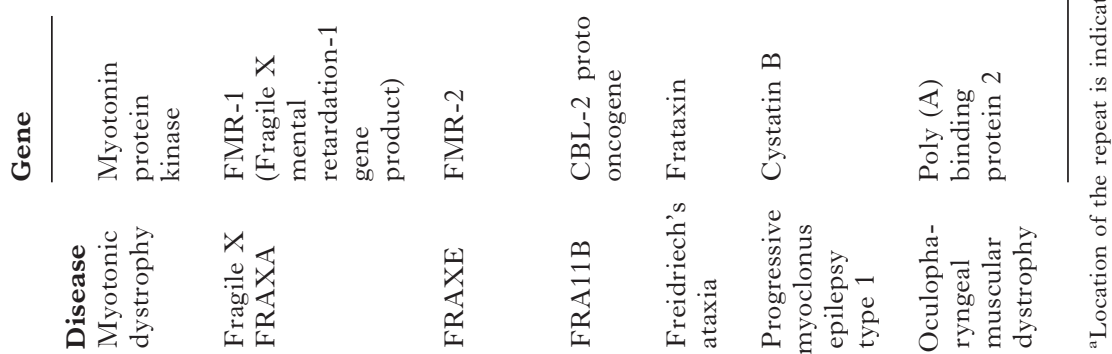

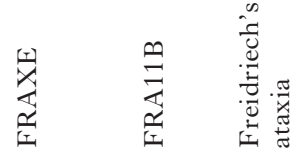

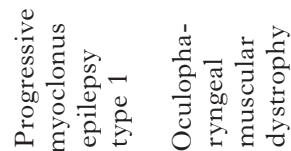



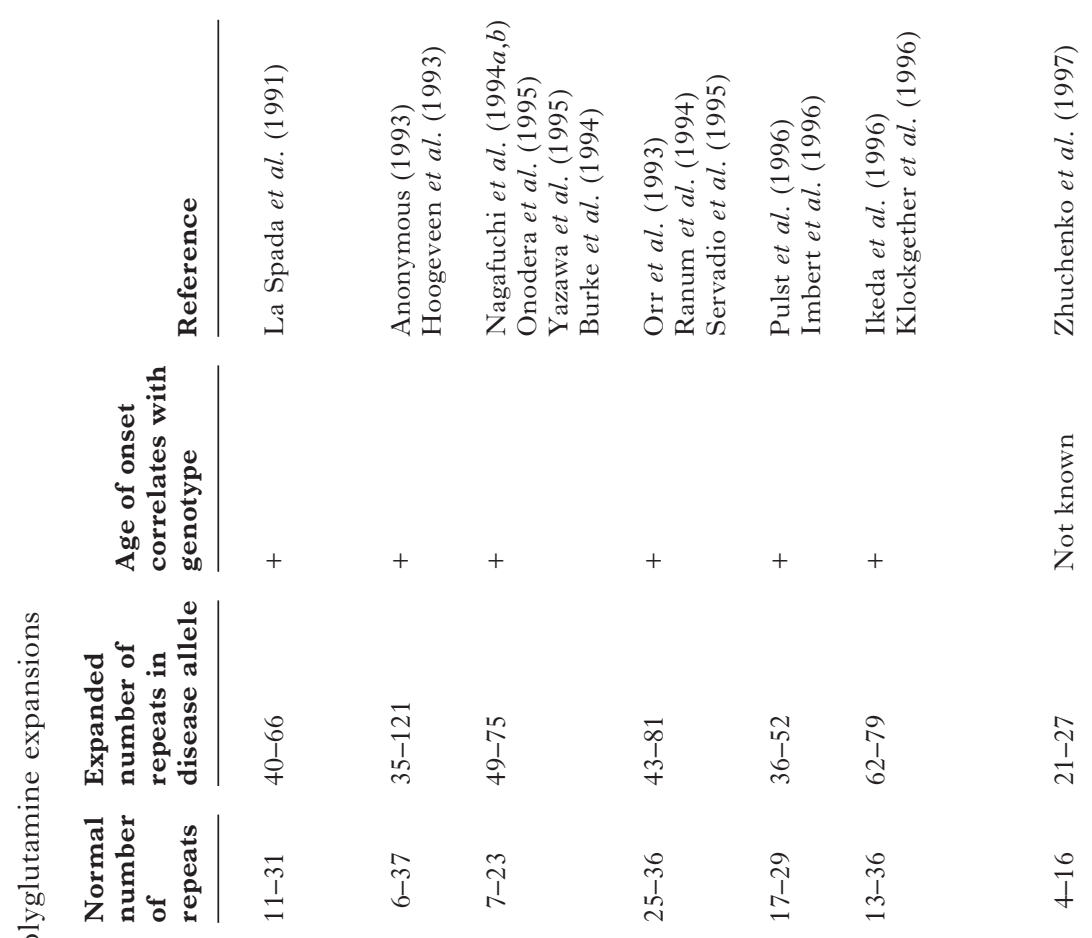

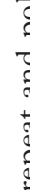

.

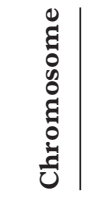

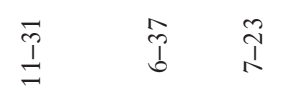

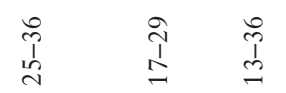

$\stackrel{0}{7}$

莺

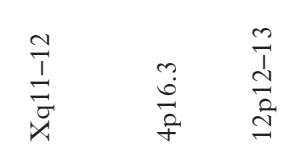

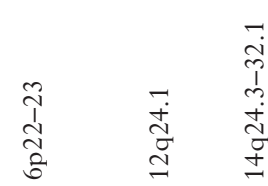

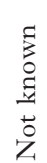

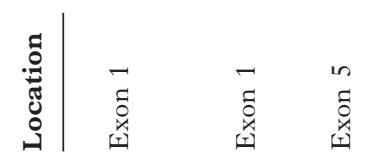

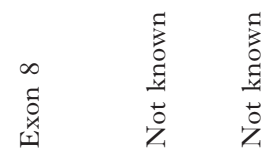

5
0
0
0
0
0
7

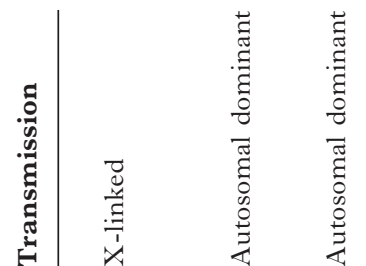

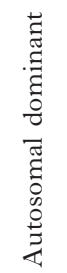

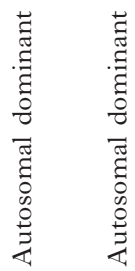

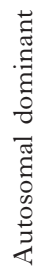

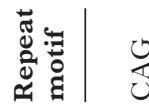

岁 岁

岕

岕 岕

岁

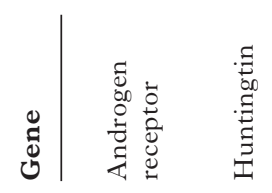

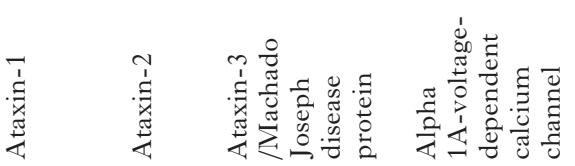

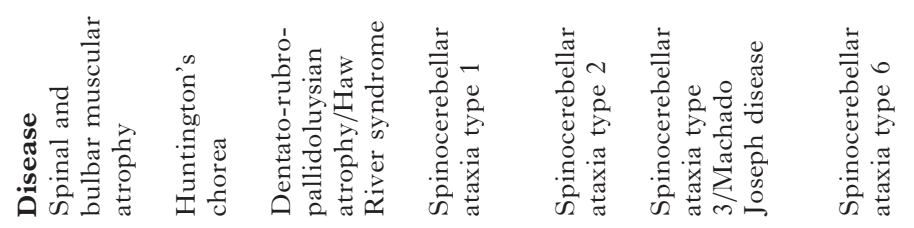


The position of the polyglutamine repeat within the protein coding region varies between different genes. For AR and huntingtin, the repeat expansion is within the amino-terminal region, whereas in atrophin, the abnormal expansion lies close to the carboxyl-terminus. The range in length of the polymorphic glutamine (Gln) tracts in the normal population is between 7 and 36 repeats. The expansion is limited in this group of disorders with the longest reported disease alleles in spinocerebellar atrophy type 1 with 81 triplet repeats. The shortest is spinocerebellar atrophy type 6 with 21 CAG repeats. It is noteworthy that 21 triplet repeats are within the normal range polymorphism for a number of the CAG repeat diseases (Table 4).

\section{X-linked spinal bulbar and muscular atrophy, Kennedy's syndrome}

X-linked SBMA first reported in two families by Kennedy et al. in 1968 is a rare inherited neurodegenerative disease characterized by progressive neuromuscular weakness resulting from loss of motor neurons in the brain stem and spinal cord. Disease onset, initially in the proximal musculature, develops in the third to fifth decades of life and is often preceded by muscular cramps on exertion, tremor of the hands and elevated muscle creatine kinase. Weakness of the facial muscles and tongue is prominent.

Expansion of the CAG polyglutamine repeat within the amino-terminus of AR was subsequently recognized as the causative mutation (La Spada et al. 1991). Consistent with other CAG repeat diseases such as Huntington's disease (Andrew et al. 1993, MacMillan et al. 1993, Snell et al. 1993), age of onset of symptoms appears to correlate inversely with CAG repeat length (Igarashi et al. 1992, La Spada et al. 1992, MacLean et al. 1995a). However, in SBMA the correlation between the molecular abnormality and either the severity of muscle weakness, or rate of progression of neuromuscular weakness (Shimada et al. 1995) and the CAG repeat length remains controversial. Expansion of AR CAG repeat sequences in X-linked SBMA pedigrees is associated with greater instability in male meioses compared with that of the female leading to a bias towards paternal transmission of mutant alleles with expanded CAG repeats (La Spada et al. 1992, Shimada et al. 1995). A similar finding was observed with the Huntington's disease allele (Andrew et al. 1993, Snell et al. 1993). However, the use of transgenic mice with yeast artificial chromosomes expressing the AR CAG repeat expansion within its genomic context provided evidence that AR CAG repeat instability increased in maternal transmission and with maternal age and may be influenced by cis-acting elements (La Spada et al. 1998). A study of 95 Japanese patients revealed an average gain in CAG repeat length on paternal transmission of 1.4 repeats (Shimada et al. 1995), significantly less than that observed in other CAG repeat diseases where a range of 9 is seen in Huntington's disease (Andrew et al. 1993, Duyao et al. 1993), 3.3 in spinocerebellar atrophy type 1 (Chung et al. 1993) and $4 \cdot 2$ in Dentato-rubropallidoluysian atrophy (Koide et al. 1994). This may account for the lesser degree of anticipation seen in SBMA compared with Huntington's disease pedigrees. In the latter disorder large differences in age of onset between parent and child do not always parallel differences in repeat length between generations (Andrew et al. 1993). The weaker correlation in Huntington's disease between the number of CAG repeats and the age of onset when there is maternal as opposed to paternal origin suggests a sex-specific modifying effect (Snell et al. 1993).

SBMA is the exception with an X-linked pattern of inheritance compared with the autosomal dominant inheritance observed for all other CAG repeat diseases. This difference may provide clues to the pathophysiology of the neurological disease, for although females express AR (Takeda et al. 1990, Ruizeveld de Winter et al. 1991, MacLean et al. 1995b), the symptoms and signs of SBMA are limited to males (Amato et al. 1993). Random X chromosome inactivation (Lyon 1972, Gartler \& Riggs 1983) or lower androgen levels (Bardin \& Lipsett 1967, Kirshner \& Bardin 1972) may account for lack of disease expression in females. Mild electromyographic abnormalities have, however, been reported in the absence of neurological and biochemical abnormality in female heterozygote carriers (Sobue et al. 1993). AR is widely expressed in many tissues (Sar et al. 1990) including the central nervous and muscular system (Sar et al. 1990, Takeda et al. 1990, Doyu et al. 1994, Doumit et al. 1996). The absence of any neuromuscular deficit or degeneration in patients with complete androgen insensitivity (Quigley et al. 1995) suggests one hypothesis that a neurotoxic gain of function by the CAG expansion mutation may be triggered by the presence of androgens.

\section{Androgen insensitivity and the CAG repeat}

In Kennedy's initial description of SBMA, one of the affected individuals had a mastectomy scar after being treated for gynaecomastia (Kennedy et al. 1968). Arbizu et al. (1983) subsequently emphasized the frequent presence of signs indicating the development of androgen insensitivity. Men with 
SBMA usually manifest varying degrees of partial androgen insensitivity including gynaecomastia, testicular atrophy, oligospermia, azoospermia and elevated serum gonadotrophins (Harding et al. 1982, Arbizu et al. 1983, Sobue et al. 1994, MacLean et al. 1995a). Diabetes mellitus is also a rare association (Harding et al. 1982, Arbizu et al. 1983). The likelihood of gynaecomastia correlates with increasing repeat length (MacLean et al. 1995a, Shimada et al. 1995). The delayed presentation of androgen resistance in SBMA compared with that associated with other AR gene mutations remains unexplained. The clinical findings suggest attrition of AR function with age and a pathophysiology probably distinct from that involved in the neurodegenerative process.

Several previous reports indicate that expansion of the Gln repeat in the $\mathrm{AR} \mathrm{NH}_{2}$-terminal region results in a structurally altered protein with reduced transcriptional capacity (Mhatre et al. 1993, Chamberlain et al. 1994, Trifiro et al. 1994, Tut et al. 1997). The findings that $\left[{ }^{3} \mathrm{H}\right] \mathrm{R} 1881$ equilibrium binding affinity and protein expression by immunoblot are usually normal in this setting support a Gln tract mediated inhibition of the transactivation function (Chamberlain et al. 1994). Others report a reduced equilibrium binding affinity of $\left[{ }^{3} \mathrm{H}\right] \mathrm{R} 1881$ in suprapubic skin fibroblasts from a normal $K_{\mathrm{d}}$ of $0.19 \mathrm{nM}$ to $0.24-11.7 \mathrm{nM}$ in SBMA patients (MacLean et al. 1995a). The change in affinity correlated with the severity of testicular atrophy and gynaecomastia (MacLean et al. 1995a). Gln lengths greater than 28 have recently been associated with an increased risk of impaired spermatogenesis (Tut et al. 1997). Our analysis using AR constructs with expanded CAG repeats in the range associated with SBMA raises an alternative hypothesis that reduced AR mRNA and protein expression (Choong et al. 1996a) may be responsible for the partially androgen insensitive phenotype.

\section{CAG EXPANSION IN THE AMINO-TERMINUS OF AR AFFECTS AR EXPRESSION}

We evaluated the effect of variation of CAG repeat length on AR RNA expression in vitro and found an inverse correlation between the length of the CAG trinucleotide repeats and the extent of AR mRNA expression and AR protein levels (Choong et al. 1996a). The CAG repeat in human AR immediately precedes a single CAA codon for Gln (Lubahn et al. 1988a) making the number of Gln residues $\mathrm{CAG}_{\mathrm{n}+1}$. Equivalent amounts of the full-length human AR expression vector DNA with $0,14,23$,
43 and 65 CAG repeats in the region of exon 1 that codes for the $\mathrm{NH}_{2}$-terminal domain were transiently expressed in monkey kidney COS cells and RNA was extracted for Northern blot analysis. AR mRNA levels were inversely related to CAG repeat length. CAG repeat lengths of 43 and 65 , which are associated with SBMA, resulted in a significant reduction in AR mRNA levels when compared with wild-type AR with 23 repeats or with 0 or 14 CAG repeats. A 4- to 5-fold reduction was observed between 0 and $65 \mathrm{CAG}$ repeats and a 2 - to 3 -fold reduction between the wild-type length of 23 $\mathrm{CAG}$ repeats to $65 \mathrm{CAG}$ repeats associated with SBMA. When the data from several experiments were normalized by rehybridization with a glyceraldehyde-3-phosphate dehydrogenase probe, there was a linear inverse relationship between CAG repeat length and levels of AR mRNA expression. Similarly, levels of AR mRNA expression in CV1 cells used in transcription assays were inversely correlated with CAG repeat length, although absolute levels were reduced relative to COS cells. Analysis of immunoblot and $\left[{ }^{35} \mathrm{~S}\right]$ methionine incorporation into expressed $\mathrm{AR}$ protein in COS cells showed a direct relationship between reduced AR $\mathrm{mRNA}$ and protein levels with reduction in AR signal intensity as the $\mathrm{CAG}$ repeat expanded to 43 and 65 . The rate of AR protein degradation using pulse/chase labelling with $\left[{ }^{35} \mathrm{~S}\right]$ methionine (Zhou et al. 1995) was not altered by variations in the length of the polyglutamine tract encoded by the CAG repeat sequences.

COS cells transfected with increasing CAG repeat-length AR expression vector DNA using calcium phosphate precipitation were analysed for AR binding affinity and capacity for $\left[{ }^{3} \mathrm{H}\right] \mathrm{R} 1881$, a radiolabelled synthetic androgen. Scatchard plot analysis revealed equivalent equilibrium binding affinity for AR encoded by sequence containing 0 , 23,43 , or 65 CAG repeats but binding capacity was reduced for AR with sequence containing 43 or 65 CAG repeats. The half-time of $\left[{ }^{3} \mathrm{H}\right] \mathrm{R} 1881$ dissociation at $37^{\circ} \mathrm{C}$ of $3 \cdot 0 \pm 0.5 \mathrm{~h}$ determined as previously described (Zhou et al. 1995) was not influenced by the 44 or 66 Gln repeat length. Thus binding capacity appeared to be the only parameter of androgen binding that was altered by expansion of the Gln repeat with the apparent equilibrium binding constant remaining unaffected. The decrease in binding capacity most likely reflected the observed decrease in AR mRNA and protein expression with CAG expansion.

Androgen-induced transcriptional activity of AR with increasing CAG repeats was tested by transient cotransfection in monkey kidney CV1 cells using a luciferase reporter vector containing the androgen 
responsive mouse mammary tumour virus promoter. Luciferase activity induced by $0 \cdot 01$ and $0 \cdot 1$ $\mathrm{nM}$ dihydrotestosterone was indistinguishable from recombinant AR of increasing Gln repeat lengths when expressed as fold induction relative to background activity determined in the absence of dihydrotestosterone. Background levels of luciferase activity detected in the absence of androgen were lower with $\mathrm{CAG}$ repeat expansion probably reflecting decreased levels of AR expression. Since the fold induction of transcriptional activation was similar to that of wild-type AR, the results suggest that increased Gln repeat lengths do not alter the inherent transcriptional activity of AR. In our studies of a family with partial androgen insensitivity, a glutamic acid to lysine mutation in the second codon of the AR gene reduces AR protein expression by alteration of the nucleotide context for translation initiation with no inherent decrease in transcriptional activation (Choong et al. 1996b). The association of the partial androgen insensitivity phenotype with reduced levels of AR expression due either to $\mathrm{CAG}$ repeat expansion or partial disruption of the initiation codon suggest that a threshold level of $\mathrm{AR}$ is required for full reproductive capacity.

\section{Reduced AR expression accounts for androgen insensitivity in X-linked SBMA}

Disruption of AR functional activity results in the syndrome of androgen insensitivity which, in its complete form, is characterized by a female external phenotype at birth and loss of normal male sexual development in $46 \mathrm{XY}$ genetic males (Quigley et al. 1995). Partial androgen insensitivity is characterized by incomplete masculinization and results from gene mutations that cause less severe disruption of AR function. AR missense mutations usually interfere with androgen or DNA binding (French et al. 1990, McPhaul et al. 1993, Brown 1995). SBMA patients undergo normal prenatal and pubertal development and are fertile, indicating the presence of a functional AR. As adults, usually after the age of 30 years (Brooks \& Fischbeck 1995) and in proportion to $\mathrm{CAG}$ repeat length, features of partial androgen resistance develop including gynaecomastia and elevated serum gonadotrophin levels (Shimada et al. 1995). Gynaecomastia in the adult male is a sensitive indicator of disturbed androgen/oestrogen ratios or of impaired androgen action mediated by AR (Wilson et al. 1980). The concentration of AR begins to decrease in the normal male between the ages of 20-30 years, as shown strikingly in human foreskin fibroblasts (Roehrborn et al. 1987). One hypothesis suggested by our findings is that adult onset androgen insensitivity observed in SBMA results from reduced AR $m R N A$ and protein production compounded by normal AR attrition and the normal age-dependent decline in androgen levels (Zumoff et al. 1982, Nahoul \& Roger 1990). During embryonic development and puberty, higher AR expression and androgen production may compensate for the inhibitory effects of the first exon expanded $\mathrm{CAG}$ repeat on AR mRNA expression allowing normal male sex development to occur.

Previous results using tissue from affected individuals support the hypothesis that reduced AR mRNA and protein expression is the molecular basis for androgen insensitivity in SBMA patients. Equilibrium androgen binding affinity was unchanged but $B_{\max }$ was reduced in SBMA patients with gynaecomastia (Warner et al. 1992). Absence of AR immunostaining in scrotal skin from affected subjects (Matsuura et al. 1992) contrasted strong immunostaining in age-matched controls indicating reduced AR protein expression in affected subjects. Reverse transcriptase-polymerase chain reaction (RT-PCR) analysis of spinal cord showed 4- to 7 -fold reduced AR mRNA levels compared with normal controls and undetectable AR protein by immunoblot analysis (Nakamura et al. 1994). This difference is greater than that observed in our studies described above and may be due to the use of the strong heterologous cytomegalovirus promoter in our AR recombinant expression vectors. Reduced androgen binding capacity with normal affinity was reported in SBMA cultured genital skin fibroblasts (Danek et al. 1994). Several clones of a stable neuronal cell line prepared with a 65 CAG repeat expansion had reduced AR protein levels compared with wild-type controls (Brooks et al. 1997).

It is important to note that subjects with complete androgen insensitivity have normal muscle strength and neuronal function indicating that reduced AR expression cannot account for the progressive muscle weakness associated with SBMA.

\section{Molecular mechanisms for reduced AR RNA expression with CAG expansion}

Decreased AR mRNA expression with CAG expansion may result from a common mechanism involving transcriptional interference. Pertinent to our findings for the CAG repeat in AR, the CTG triplet repeat in the mouse growth inhibitory factor/metallothionein III gene promoter represses transcriptional activity in a direction- and positionindependent manner (Imagawa et al. 1995). One possible mechanism for transcriptional interference by trinucleotide repeat expansion is preferential 
nucleosome assembly. In myotonic dystrophy and Huntington's disease, electron microscopy reveals increased nucleosome formation at the expanded CTG (CAG) triplet repeat that could interfere with transcription complex progression (Wang et al. 1994). Although CTG repeat expansion failed to enhance nucleosome formation, preferential nucleosome assembly in the repeat region was thought to contribute to repeat expansion (Godde \& Wolffe 1996). The repeat length associated with most triplet repeat disease phenotypes correlates with the length of DNA required for nucleosome formation (146 bp).

A number of other mechanisms by which expanded triplet repeat sequences could result in transcriptional interference have been described. For example hypermethylation of CGG triplet repeats causes reduced expression of the fragile $\mathrm{X}$ mental retardation gene (Pieretti et al. 1991), RNA polymerase pausing proportional to repeat length (Kang et al. 1995b), formation of hairpin structures by triplet repeats (Nadel et al. 1995, Wells 1996) and intermolecular DNA triplex formation (Ohshima et al. 1996). With respect to the AR, our studies raise the possibility that reduced mRNA levels associated with the $\mathrm{CAG}$ trinucleotide repeat expansion could result from abnormal association with RNA binding proteins.

Experimental data from Ikeda et al. (1996) indicate accelerated apoptosis in transfected cells and reduced expression of the Machado-Joseph disease protein type 1 fragments containing the expanded polyglutamine repeat. Scherzinger et al. (1997) found the expression of glutathione-S-transferase (GST)-fusion huntingtin protein containing 83 and 122 polyglutamine repeats to be markedly reduced compared with that of proteins with less than 35-40 Gln repeats. Scherzinger et al. (1997) proposed that the reduced expression of the truncated protein may be due to accelerated cell death. Contrary to this hypothesis we noted equivalent levels of glyceraldehyde-3-phosphate dehydrogenase expression in total RNA extracted from a standard number of cells. We did not observe a difference in cell density at the time of RNA extraction. However, we did not exclude the possibility that accelerated apoptosis contributes to reduced AR mRNA expression observed in our studies.

\section{HYPOTHESES FOR NEUROTOXICITY OF THE CAG EXPANSION}

\section{Altered RNA metabolism may contribute to CAG repeat associated disease pathogenesis}

Although the CAG repeat gene products are heterogeneous in their cellular location, function and presence in coding sequences, expression as mRNA is a common feature making RNA metabolism a possible site of altered function. The known interaction between mRNAs and small nuclear ribonucleoproteins and RNA-binding proteins suggests a possible site of action (Dreyfuss et al. 1988).

McLaughlin et al. (1996) isolated a $63 \mathrm{kDa}$ RNA-binding protein from human and rat cortical and striatal extracts that specifically interacts with the CAG repeat sequence in cRNA transcribed in vitro from huntingtin and $\mathrm{AR}$ constructs. The efficiency of the interaction depended on the length of the CAG repeat (McLaughlin et al. 1996). Our finding of an inverse correlation between CAG repeat length and $\mathrm{AR}$ mRNA expression (Choong et al. 1996a) may be a consequence of an inappropriate RNA binding-protein interaction with specific mRNA which may disturb cellular dynamics or alter the regulation, transport and expression of CAG containing RNA.

In support of this hypothesis, recent work by Davis et al. (1997) demonstrated increased nuclear retention of mutant RNA transcripts of the myotonic dystrophy protein kinase containing the CTG expansion in differentiated cultured myoblasts. The mutant transcripts are polyadenylated and spliced, form stable clusters that are tightly linked to the nuclear matrix, and do not appear to have decreased stability in experiments where actinomycin D is used to block RNA synthesis (Davis et al. 1997). Hamshere et al. (1997) observed both nuclear retention and reduced polyadenylated mutant expanded myotonic dystrophy protein kinase transcripts. These findings for myotonic dystrophy have not been tested for the CAG repeat diseases.

\section{Protein-protein interactions}

The mechanism whereby an expanded polyglutamine repeat leads to neurodegenerative disease and the underlying mechanism for the susceptibility of neuronal tissue to the pathogenic consequences of CAG expansion are unknown. The mode of inheritance and ubiquitous expression of the mutant proteins in tissues from affected individuals (Strong et al. 1993) and the gene-specific localization of pathology suggests a gain of toxic function dependent on specific neuronal factors (Paulson \& Fischbeck 1996).

Polyglutamine tracts are functionally important domains in a number of ubiquitous transcription factors (Mitchell \& Tjian 1989, Gerber et al. 1994). The AR is the only gene product of the CAG trinucleotide repeat diseases with a clearly defined 
functional role as a transcription factor (Zhou et al. 1994). One hypothesis is that the expanded AR CAG repeat interacts with as yet unspecified cofactors to cause aberrant transcriptional activation of genes within the neuron resulting in accelerated degeneration.

A number of protein-protein interactions with potential pathogenic significance have been proposed and demonstrated by a variety of techniques. Using the yeast two hybrid protein interaction assay and in vitro binding with glutathione $\mathrm{S}$-transferase fusion proteins, the huntingtin-associated protein (HAP)-1 (Li et al. 1995) was discovered. This protein is selectively expressed in the brain, with enhanced binding in the presence of expanded huntingtin Gln repeat lengths as seen in Huntington's disease patients. The polyglutamine region of huntingtin has also been shown to interact with calmodulin in a calcium-dependent fashion (Bao et al. 1996).

Glyceraldehyde-3-phosphate dehydrogenase is a ubiquitous multifunctional enzyme essential to glycolysis. It interacts selectively with the normal polyglutamine proteins of Huntington's disease and dentorubral pallidoluysian atrophy (Burke et al. 1996, Roses 1996) as well as the polyglutamine region of the spinocerebellar atrophy type 1 gene product ataxin-1 and the AR (Koshy et al. 1996). Other potential huntingtin interacting proteins include a ubiquitin-conjugating enzyme (Kalchman et al. 1996) and a human homologue of S. cerevisiae Sla2p, shown to be important in cytoskeletal integrity (Kalchman et al. 1997, Wanker et al. 1997).

Goldberg et al. (1996) reported accelerated degradation of huntingtin by apoptotic extracts and by the key proteolytic enzyme apopain, the human counterpart of the nematode cysteine protease death-gene product, CED-3. The rate of cleavage of huntingtin was coincident with activation of apopain and increased with the length of the polyglutamine repeat (Goldberg et al. 1996). Post mortem examination of neural tissue from patients with Huntington's disease suggests that accelerated apoptosis occurs with increased non-random distribution of DNA fragmentation in cells in the corpus striatum compared with normals (Dragunow et al. 1995). In the neostriatum of individuals with Huntington's disease, the pattern of distribution of TUNEL (TdT-mediated dUTP-digoxigenin nick end-labeling)-positive apoptotic neurons and glia was similar to that seen during normal development of the nervous system (Portera-Cailliau et al. 1995). One hypothesis suggested by these observations is that amino-terminal protein fragments with expanded polyglutamine tracts that result from accelerated degradation of huntingtin by proteases such as apopain, associate with glyceraldehyde3 -phosphate dehydrogenase, thereby disrupting energy metabolism and promoting the neuroatrophy (Vonsattel et al. 1985, Myers et al. 1991) observed in Huntington's disease.

It is conceivable that the polyglutamine region interacts with a number of cellular proteins. In some of these interactions a variation in the polyglutamine length could affect the tenacity of the interaction. Altered protein-protein interactions with the polyglutamine region have been demonstrated by several methods, lending support to a gain of function theory.

Perutz et al. (1994) suggested that Gln repeats function as polar zippers, for example, joining specific transcription factors bound to separate DNA segments. Glutamine expansions may cause disease by increased nonspecific affinity between such factors or by gradual precipitation of the affected proteins in neurons (Perutz et al. 1994). Another proposed neuropathic mechanism is cellular toxicity resulting from enhanced aggregation of proteins with an expanded polyglutamine tract secondary to transglutaminase cross-linking (Green 1993). Accumulation over time of these toxic products or, more likely, a sequestration of critical proteins from their normal function, could account for the relationship between polyglutamine length and age of onset of the neurodegenerative phenotype.

Scherzinger et al. (1997) have shown that proteolytic cleavage of a GST-huntingtin fusion protein leads to formation of insoluble high molecular weight protein aggregates when the protein contains a polyglutamine expansion which is in the pathological range. When analysed by SDS-polyacrylamide gel electrophoresis, insoluble high molecular weight proteins were detected with proteins containing the expanded polyglutamine tracts of 81 or 122 repeats. The critical length for formation of aggregates in these experiments was suggested to be between 35 and 40 repeats. Electron micrographs of these aggregates revealed a fibrillar structure reminiscent of $\beta$-amyloid fibrils in Alzheimer's disease and resembled the intranuclear inclusion bodies detected in symptomatic mice transgenic for the Huntington's disease mutation. Recombinant proteins migrated at a size corresponding closely to the predicted molecular weight when still part of the fusion protein. However, when the GST tag was removed by trypsin, HD51 migrated with two protein products at 37 and $60 \mathrm{kDa}$.

Transgenic experiments in mice overexpressing the expanded polyglutamine domain of either ataxin 1 (Burright et al. 1995) or the isolated 
polyglutamine tract of the spinocerebellar atrophy type 3 gene into Purkinje cells (Ikeda et al. 1996) suggest that accelerated apoptosis of specific neurons contributes to neurodegeneration. Of particular note, no phenotype was observed in mice overexpressing the entire mutated expanded spinocerebellar atrophy type 3 gene (Ikeda et al. 1996). However, mice transgenic for the $5^{\prime}$ end of the human Huntington's disease gene carrying $(\mathrm{CAG})_{115}$ to $(\mathrm{CAG})_{150}$ repeat expansions demonstrated a progressive neurological syndrome that exhibited many of the characteristic features of Huntington's disease (Mangiarini et al. 1996). The transgene was ubiquitously expressed with some variability in tissue levels. The movement disorder in the transgenic Huntington's disease mice was distinct from that reported for mice transgenic for the spinocerebellar atrophy type genes (Burright et al. 1995, Ikeda et al. 1996). Nor was there evidence for muscular atrophy as seen in SBMA, indicating that the effect of the polyglutamine repeat is specific to the protein in which it occurs.

Using antibodies directed to the amino-terminus of huntingtin just proximal to the expanded CAG repeat (amino acids 1-17), Davies et al. (1997) demonstrated that mice transgenic for exon 1 of the human Huntington's disease gene carrying $(\mathrm{CAG})_{115}$ to $(\mathrm{CAG})_{156}$ repeat expansions developed neuronal intranuclear inclusions containing the proteins huntingtin and ubiquitin prior to the onset of the neurological disorder. Immunoreactivity in symptomatic transgenic mice was specifically concentrated as a densely stained circular intranuclear inclusion within the neuronal but not glial cells. Antibodies which recognize regions outside the transgene did not stain the inclusion, indicating that endogenous mouse huntingtin protein did not co-localize with the ectopic transgenic protein. Immunocytochemical analysis demonstrated localization of ubiquitin in the nuclear inclusion. While accumulation of reaction product was also evident within the cytoplasm, there was no co-localization of ubiquitin in these cytoplasmic vesicles. More frequent indentations and an apparent increased density of pores in the nuclear membrane was also associated with the intranuclear inclusion. The temporal expression of the intranuclear inclusion bodies preceded onset of the neurological disorder and loss of brain and body weight in symptomatic transgene animals (Davies et al. 1997), supporting a causal role in the etiology of the neurological disorder. Detection of neuronal intranuclear inclusion bodies by immunocytochemistry using antiserum to the huntingtin amino-terminal epitope (amino acids 1-17) in post mortem brain tissue from Huntington's disease patients suggests that these inclusions play a role in the pathophysiology of Huntington's disease (DiFiglia et al. 1997). The neuronal distribution of the intranuclear inclusion bodies, the higher incidence of these aggregations in brains from juvenile onset Huntington's disease patients, and their absence in a presymptomatic adult support this hypothesis (DiFiglia et al. 1997).

A recent report by Ordway et al. (1997) of late onset neurological disease associated with neuronal intranuclear inclusion in transgenic mice expressing a mutant hypoxanthine phosphoribosyltransferase protein containing an expanded CAG repeat of 146 residues encoded within exon 3 suggests that the neurotoxicity of the polyglutamine repeat relates to its presence in smaller or truncated proteins.

\section{STRUCTURAL EFFECTS OF CAG REPEAT EXPANSION IN AR}

${ }^{35} \mathrm{~S}$-Methionine labelling of AR amino-terminal fragments with increasing CAG repeat lengths up to 64 , where 64 was derived from a patient with SBMA (La Spada et al. 1992), resulted in alterations in the spacing and migration of the AR fragments on SDS gels that was not accounted for simply by changes in molecular weight (Choong et al. 1998). Spacing between the double bands which resulted from phosphorylation was greatest for a frequent polymorphism (23 CAG) in the normal human population. Correlation between CAG repeat length and increased spacing between doublet bands has been reported previously (Jenster et al. 1994). AR migration on SDS gels appeared to be influenced by both CAG repeat length and serine 94 phosphorylation, raising the possibility of a structural interaction between serine 94 phosphate and the CAG Gln repeat that persists in the presence of SDS. With isotope dilution, the bands shifted to the upper band. From the extent of band shift, phosphorylation occurs more rapidly as the CAG repeat expands. About $90 \%$ of the lower band shifts for CAG 64 whereas CAG 4 from lemur remains predominantly in the lower unphosphorylated form, suggesting that CAG repeat length alters the rate of serine 94 phosphorylation. This conclusion is supported by the lack of change in migration during isotope dilution of $\mathrm{AR}$ fragments which have a serine 94 to alanine mutation and fragments in which the CAG repeat is deleted in $\Delta 14-83$.

We and others have observed the SDS polyacrylamide gel electrophoresis mass of full-length AR containing the expanded CAG repeat is close to the calculated mass (Jenster et al. 1994, Choong et al. 1996a). However migration of truncated 
AR fragments during SDS polyacrylamide gel electrophoresis was retarded suggesting formation of higher molecular weight complexes possibly due to aggregation of the truncated fragments. This observation of altered migration of the AR truncated fragment raises the possibility of a common pathogenic mechanism for neurodegeneration for the CAG triplet repeat diseases whereby protein aggregation may occur after AR proteolysis to smaller fragments encompassing an expanded $\mathrm{CAG}$ repeat and thus contribute to loss of neuronal cell function associated with SBMA. Full-length human AR with 44 glutamines expressed in transfected COS cells was more resistant to proteolysis by trypsin compared with wild-type AR with 20 glutamines. In these studies COS cells transfected with human AR with $(\mathrm{CAG})_{44}$ showed increased apoptosis compared with cells expressing wild-type AR (Abdullah et al. 1998). A pathophysiological mechanism such as this is consistent with the observation that full-length AR with CAG repeat sequence expanded into the pathological range has functional activity similar to that of the wild-type receptor and supports normal male sexual development and function until adulthood. Cytoplasmic aggregation of an $\mathrm{AR} \mathrm{NH}_{2}$-terminal fragment with overexpression of full-length $\mathrm{AR}$ with an expanded CAG repeat in mouse neuroblastoma NB2a/d1 cells treated with androgen suggested that protein aggregation may contribute to the phenotype of SBMA (Butler et al. 1998).

\section{Strategies for further investigation of androgen receptor-mediated neurodegeneration}

Our observation of altered migration of an insoluble AR truncated fragment supports a common pathogenic pathway for neurodegeneration in CAG triplet repeat diseases. We postulate that $\mathrm{AR}$ with an expanded CAG repeat is preferentially digested by a protease. Aggregated AR fragments may accrue with time, resulting in the formation of insoluble complexes which trigger apoptosis. Evidence for this pathway might derive from the demonstration of accelerated apoptosis in anterior spinal horn cells from individuals with spinal bulbar and muscular atrophy, aggregation of truncated AR fragments in the nuclear compartments of these neurons, and the identification of the proteolytic enzymes that interact specifically with $\mathrm{AR}$ in the anterior horn cells. Localization of putative proteolytic enzymes to the nuclear or cytoplasmic compartments would suggest strategies for manipulating the aberrant pathway via the AR nuclear targeting signal. In the light of our findings of reduced
AR mRNA levels with expanded CAG repeat length, altered RNA metabolism is potentially another mechanism involved in the neurological dysfunction associated with the expanded CAG repeat in AR. Elucidation of pathways involving the role of CAG repeats as cis acting regulatory elements for AR mRNA, stability of AR mRNA metabolism in neuronal and nonneuronal cells, and the effects on function of other critical mRNAs or proteins, will provide insight into the pathophysiology of neurodegeneration and suggest strategies for prevention.

\section{FUNCTIONAL SIGNIFICANCE OF THE AR CAG REPEAT POLYMORPHISM IN PROSTATE CANCER}

The AR is critical for the normal development of the male urogenital tract. During embryogenesis AR is initially expressed in mesenchymal cells of the urogenital anlagen (Husmann et al. 1991). In the presence of androgen there is increased expression of AR positive mesenchymal cells and subsequent expression of receptor in epithelial cells (Bentvelsen et al. 1995). Differentiation of the prostatic epithelial cells is triggered by androgen (Cunha et al. 1987). The absence of prostatic development in complete androgen insensitivity syndrome (Quigley et al. 1995) and in individuals with $5 \alpha$-reductase type 2 deficiency (Thigpen et al. 1992) underscores the primary role of the AR and $5 \alpha$-dihydrotestosterone in prostatic development in humans. The secretory epithelium of the mature prostate expresses high levels of AR, but the interaction between the mesenchyme and epithelial compartments is not clearly defined. Maintenance of prostatic architecture and function in the adult has been shown to be dependent on androgen action (Cunha et al. 1987, Moorandian et al. 1987).

Prostate cancer is a major cause of mortality and morbidity in the aging populations of industrialized countries. Current screening methods have resulted in increased detection of early localized disease, albeit with no appreciable change in prostate cancer-related mortality thus far (Lu-Yao \& Greenberg 1994). Ninety-five percent of prostate cancers are adenocarcinomas which derive from the secretory acinar. There is a correlation between the degree of prostate tumour differentiation and AR content (Chodak et al. 1992). The majority of prostate cancers at diagnosis are hormone dependent, and androgen drug ablation with orchiectomy or luteinizing hormone-releasing hormone agonists and antiandrogen administration are standard therapeutic approaches. Meta-analysis of 22 ran- 
domized trials demonstrated a mortality rate of $57 \%$ in patients with metastatic disease at 40 months after treatment with no significant survival difference between groups treated with surgical castration or maximal androgen blockade (Anonymous 1995). Although androgen ablation induces remission in a significant proportion of patients (Gittes 1991), the subsequent emergence of hormone independent tumours often leads to relapse (Frydenberg et al. 1997). A positive family history strongly predicts the likelihood of developing prostate cancer (Hayes et al. 1995, Narod et al. 1995, Whittemore et al. 1995) with a calculated relative risk of $2.62(95 \%$ confidence interval (CI) 1.69-4.06) in patients with affected brothers and 1.22 (95\% CI 0.77-1.94) in those with affected fathers (Narod et al. 1995). The higher relative risk in brothers observed in these case control studies suggests an X-linked genetic contribution to disease pathogenesis (Hayes et al. 1995, Narod et al. 1995).

The pathological role of $\mathrm{AR}$ in prostate carcinogenesis, metastases and in the evolution of hormone refractoriness is not well understood. Irvine et al. (1995) investigated possible linkage disequilibrium between the CAG and GGC microsatellites of AR and observed an association between shorter $(<22$ repeats) CAG alleles and longer ( $>16$ repeats) GGC alleles and increased risk of prostate cancer in Caucasian males. A significant correlation between CAG repeat length and age at onset was observed in one study of 109 men (Hardy et al. 1996). A large prospective case control study of 587 predominantly Caucasian $(>95 \%)$ subjects from the Physician's Health Study demonstrated an inverse relationship in all age groups between $\mathrm{CAG}$ repeat length and risk of aggressive prostate cancer, as characterized by high histological grade, distant metastases at diagnosis and disease-related mortality (Giovannucci et al. 1997). Two further studies support an association between reduced AR CAG repeat length with increased risk of prostate cancer, with the length of the polymorphic GGC repeat being an additional potential risk factor for development of prostate cancer (Hakimi et al. 1997, Stanford et al.1997). A survey of 11125 patients 40 years or older with no evidence of prostate cancer from the Baltimore Veterans Affairs Medical Center reported that the normal range for prostate-specific antigen was higher in African American males than in Caucasians in all age groups. The greatest difference was in those men aged 70 years or over, where the ratio was 1.6 (Sawyer et al. 1996, 1997). African American males have previously been shown to have a distribution of CAG repeats in the AR gene which is shifted to slightly shorter repeat lengths (Irvine et al. 1995). These findings provide circumstantial evidence for in- creased AR expression and activity in vivo resulting from variation in the length of the CAG tandem repeat and could partially account for the higher incidence of prostate cancer (Boring et al. 1992) in African Americans compared with Caucasian males in the United States.

Progression of prostate cancer is associated with genetic instability. Reported genetic aberrations include allelic loss of chromosome $8 \mathrm{p}$ in $50 \%$ of cases (Boring et al. 1992) and loss of heterozygosity in $20-30 \%$ of cases for chromosome regions $10 \mathrm{q}$, $16 \mathrm{p}$, and 17p (Cannon-Albright \& Eeles 1995). Mutations in the ras oncogene, the p53 tumour suppressor gene, trisomy 7 and the MXI1 gene (Eagle et al. 1995) have also been observed. The majority of somatic AR mutations were detected in hormone refractory cancer or in the setting of advanced metastatic disease (Gaddipati et al. 1994, Taplin et al. 1995, Suzuki et al. 1996). Tilley and coworkers (1996) identified mutations in 11 of 25 primary prostate tumours sampled prior to initiation of hormone therapy using single strand polymorphism screening of PCR products. Eight missense mutations were identified in exon 1 . Although the functional effects of individual mutations were not characterized in vitro, the presence of AR amino acid mutations is associated with decreased intensity of immunocytochemical staining for AR in tumour cells and a significant correlation with poor response to hormone therapy (Tilley et al. 1996).

The importance of altered androgen responsiveness in tumour progression is supported by the identification of somatic mutations in $\mathrm{AR}$ from prostate cancer that alter ligand binding specificity (Veldscholte et al. 1990, Newmark et al. 1992, Culig et al. 1993). A somatic microsatellite mutation in the CAG trinucleotide repeat region resulting in a reduction from 24 to 18 repeats was identified in one out of forty prostate adenocarcinoma specimens of various grades obtained at radical prostatectomy and screened for mutations at this locus (Schoenberg et al. 1994). Although only the CAG repeat was analysed, the authors postulate that the high relative abundance of the mutant allele was evidence for a selective growth advantage conferred by contraction of the CAG repeat in the AR gene. Despite the reported incidence of $14.6 \%$ microsatellite instability in advanced disease (Suzuki et al. 1995), mutation at the AR CAG repeat has rarely been reported. This may reflect the fact that the DNA and ligand binding domains are the regions most commonly screened for mutations. In addition, the high GC content of the region of the $\mathrm{AR}$ gene that encodes the amino-terminal domain may lower the sensitivity of screening techniques 
such as denaturing gradient gel electrophoresis (De Bellis et al. 1992) for detection of CAG mutations. This does not appear to be the case, however, by single strand polymorphism screening of PCR products (Tilley et al. 1996).

Studies of hormone refractory tumours demonstrated a 4-fold AR gene amplification relative to $\mathrm{X}$ chromosome copy number in 30\% of specimens using fluorescent in situ hybridization with an AR specific and $\mathrm{X}$ chromosome reference probe. These results suggest that $A R$ is important in the development of acquired hormone resistance. Of note, significant intratumour variability was observed with individual cells expressing 5-60 AR genomic copies/cell and no evidence of AR gene amplification in paired untreated tumour samples. Both primary and recurrent tumours demonstrated strong nuclear staining, suggesting a transcriptionally active AR (Visakorpi et al. 1995). In a larger clinical study of 54 patients, the same group reported concomitant $\mathrm{AR}$ gene overexpression by mRNA in situ hybridization in AR amplified recurrent tumour samples. There was a more favourable response to primary therapy and longer median post recurrence survival in these patients compared with those where no amplification was observed (Koivisto et al. 1997). One implication of this work is that AR amplification with enhanced expression in hormone responsive tumours may confer a proliferative advantage by allowing cells to resume androgen dependent growth in a low androgen environment (Koivisto et al. 1997).

\section{CONCLUSIONS}

Given the structural constraints on the DNA and ligand binding domains, the effects of the CAG trinucleotide repeat length on $\mathrm{AR}$ expression and phosphorylation may set the background level of AR activity in response to androgen stimulation. Polymorphic variation of the CAG repeat in human AR probably contributes to the observed individual phenotypic differences in androgenization. It may also be one determinant of the magnitude of cellular responses to carcinogenic events that induce the development of prostate cancer.

\section{Will the AR gene CAG expansion continue?}

Short reiterated microsatellite sequences of 1-5 nucleotides tend to lengthen in humans relative to other primates suggesting that microsatellite evolution is directional (Rubinsztein et al. 1995a) and may result from a mutational bias towards longer repeats. In non-human primates, CAG iteration is shorter in the AR and other genes associated with human neurodegenerative diseases (Rubinsztein et al. 1995b, Djian et al. 1996). Although no universal model accounts for expanding trinucleotide repeats during mammalian evolution, older age at reproduction in human males compared with non-human primates or a larger pool of heterozygote alleles associated with a diverse population, could contribute to higher mutation rates (Rubinsztein et al. 1995a).

Natural selection tends to eliminate harmful mutations and maintain advantageous ones, yet silent mutations with no adaptive advantage can become fixed in a genome and reflect time of divergence of a species (Ayala 1995). Evolutionary expansion of the AR CAG repeat sequence may reflect natural selection rather than a neutral expanding polymorphism. CAG repeat expansion is associated with reduced AR expression and a Gln repeat-serine phosphate structural motif. Exponential expansion of the AR CAG repeat during primate evolution might continue into the range associated with androgen insensitivity and neurodegeneration. However, the deleterious effects that could result from reduced AR expression and gain-of-function defects would be expected to impair human fertility and thus arrest the expansion through natural selection.

\section{ACKNOWLEDGEMENTS}

For providing primate blood samples, we thank Michael Adams, Debbie Golden and Claude L Hughes, Department of Comparative Medicine, Bowman Gray School of Medicine, Wake Forest University for macaque, Lorraine Meller, North Carolina Zoological Park for chimpanzee, Kenneth Glander and Cathy Williams, Duke University Primate Center for lemur, and David J Handelsman, Royal Prince Alfred Hospital, University of Sydney, Australia, for baboon from the self sustaining National Health and Medical Research Council National Baboon breeding colony, supported by the Australian National Health and Medical Research Council, Bullens Primate Research Foundation and the Medical Foundation of the University of Sydney. We thank Rytas Vilgalys at Duke University for advice, Jon A Kemppainen and $\mathrm{K}$ Michelle Cobb for technical assistance and John $\mathrm{R}$ Dyer for reading the manuscript. The work was supported by grants HD16910 and HD35041 from the National Institute of Child Health and Human Development Center for Population Research, Research Award 95-193 from the Genentech Foundation for Growth and Development and by the Andrew W Mellon Foundation. 


\section{REFERENCES}

Abdullah AAR, Trifiro MA, Panet-Raymond V, Alvarado C, de Tourreil S, Frankel D, Schipper HM \& Pinsky L 1998 Spinobulbar muscular atrophy: polyglutamine-expanded androgen receptor is proteolytically resistant in vitro and processed abnormally in transfected cells. Human Molecular Genetics 7 379-384.

Amato AA, Prior TW, Barohn RJ, Snyder P, Papp A \& Mendell JR 1993 Kennedy's disease: a clinicopathologic correlation with mutations in the androgen receptor gene. Neurology 43 791-794.

Andrew SE, Goldberg YP, Kremer B, Telenius H, Theilmann J, Adam S, Starr E, Squitieri F, Lin B, Kalchman MA, Graham RK \& Hayden MR 1993 The relationship between trinucleotide $(\mathrm{CAG})$ repeat length and clinical features of Huntington's disease. Nature Genetics 4 398-403.

Anonymous 1993 A novel gene containing a trinucleotide repeat that is expanded and unstable on Huntington's disease chromosomes. The Huntington's Disease Collaborative Research Group. Cell 72 971-983.

Anonymous 1995 Maximum androgen blockade in advanced prostate cancer: an overview of 22 randomized trials with 3283 deaths in 5710 patients. Prostate Cancer Trialists' Collaborative Group. Lancet 346 265-269.

Arbizu T, Santamaria J, Gomez JM, Quilez A \& Serra JP 1983 A family with adult onset spinal and bulbar muscular atrophy, X-linked inheritance and associated testicular failure. Fournal of the Neurological Sciences 59 371-382.

Arriza JL, Weinberger C, Cerelli G, Glaser TM, Handelin BL, Housman DE \& Evans RM 1987 Cloning of human mineralocorticoid receptor complementary DNA: structural and functional kinship with the glucocorticoid receptor. Science 237 268-275.

Ashizawa T, Dunne PW, Ward PA, Seltzer WK \& Richards CS 1994 Effects of the sex of myotonic dystrophy patients on the unstable triplet repeat in their affected offspring. Neurology 44 120-122.

Ayala FJ 1995 The myth of Eve: molecular biology and human origins. Science 270 1930-1936.

Bao J, Sharp AH, Wagster MV, Becher M, Schilling G, Ross CA, Dawson VL \& Dawson TM 1996 Expansion of polyglutamine repeat in huntingtin leads to abnormal protein interactions involving calmodulin. Proceedings of the National Academy of Sciences of the USA 93 5037-5042.

Bardin CW \& Lipsett MB 1967 Testosterone and androstenedione blood production rates in normal women and women with idiopathic hirsutism or polycystic ovaries. Fournal of Clinical Investigation 46 891-902.

Batch JA, Williams DM, Davies HR, Brown BD, Evans BA, Hughes IA \& Patterson MN 1992 Androgen receptor gene mutations identified by SSCP in fourteen subjects with androgen insensitivity syndrome. Human Molecular Genetics $1497-503$.

Bentvelsen FM, Brinkmann AO, van der Schoot P, van der Linden JE, van der Kwast TH, Boersma WJ, Schroder FH \& Nijman JM 1995 Developmental pattern and regulation by androgens of androgen receptor expression in the urogenital tract of the rat. Molecular and Cellular Endocrinology 113 $245-253$.

Boring CC, Suites TS \& Heath CW 1992 Cancer statistics for African Americans. CA Cancer Fournal Clinics 43 7-17.

Brais B, Bouchard JP, Xie YG, Rochefort DL, Chretien N, Tome FM, Lafreniere RG, Rommens JM, Uyama E, Nohira O, Blumen S, Korcyn AD, Heutink P, Mathieu J, Duranceau A, Codere F, Fardeau M \& Rouleau GA 1998 Short GCG expansions in the PABP2 gene cause oculopharyngeal muscular dystrophy. Nature Genetics 18 164-167.
Brooks BP \& Fischbeck KH 1995 Spinal and bulbar muscular atrophy: a trinucleotide-repeat expansion neurodegenerative disease. Trends in Neurosciences 18 459-461.

Brooks BP, Paulson HL, Merry DE, Salazar-Greuso EF, Wilson EM \& Fischbeck KH 1997 Characterization of the spinal-and-bulbar muscular atrophy gene in a neuronal cell culture system. Neurobiology of Disease 4 313-323.

Brown CJ, Goss SJ, Lubahn DB, Joseph DR, Wilson EM, French FS \& Willard HF 1989 Androgen receptor locus on the human X chromosome: regional localization to Xq11-12 and description of a DNA polymorphism. American fournal of Human Genetics 44 264-269.

Brown TR 1995 Human androgen insensitivity syndrome. Fournal of Andrology 16 299-303.

Burke JR, Wingfeild MS, Lewis KE, Roses AD, Lee JE, Hulette C, Pericak-Vance MA \& Vance JM 1994 The Haw River syndrome: dentatorubropallidoluysian atrophy (DPRLA) in an African American-family. Nature Genetics 7 521-524.

Burke JR, Enghild JJ, Martin ME, Jou YS, Myers RM, Roses AD, Vance JM \& Strittmatter WJ 1996 Huntingtin and DRPLA proteins selectively interact with the enzyme GAPDH. Nature Medicine 2 347-350.

Burright EN, Clark HB, Servadio A, Matilla T, Feddersen RM, Yunis WS, Duvick LA, Zoghbi HY \& Orr HT 1995 SCA1 transgenic mice: a model for neurodegeneration caused by an expanded CAG trinucleotide repeat. Cell 82 937-948.

Butler R, Leigh PN, McPhaul MJ \& Gallo J-M 1998

Truncated forms of the androgen receptor are associated with polyglutamine expansion in X-linked spinal and bulbar muscular atrophy. Human Molecular Genetics 7 121-127.

Campuzano V, Montermini L, Molto MD, Pianese L, Cossee M, Cavalcanti F, Monros E, Rodius F, Duclos F \& Monticelli A 1996 Friedreich's ataxia: autosomal recessive disease caused by an intronic GAA triplet repeat expansion. Science 271 1423-1427.

Cannon-Albright L \& Eeles R 1995 Progress in prostate cancer. Nature Genetics 9 336-338.

Chamberlain NL, Driver ED \& Miesfeld RL 1994 The length and location of CAG trinucleotide repeats in the androgen receptor N-terminal domain affect transactivation function. Nucleic Acids Research 22 3181-3186.

Chang C, Kokontis J \& Liao S 1988 a Molecular cloning of human and rat complementary DNA encoding androgen receptors. Science 240 324-326.

Chang C, Kokontis J \& Liao S $1988 b$ Structural analysis of complementary DNA and amino acid sequences of human and rat androgen receptors. Proceedings of the National Academy of Sciences of the USA 85 7211-7215.

Chodak GW, Kranc DM, Puy LA, Takeda H, Johnson K \& Chang C 1992 Nuclear localization of androgen receptor in heterogeneous samples of normal, hyperplastic and neoplastic human prostate. Fournal of Urology 147 798-803.

Choong CS, Kemppainen JA, Zhou Z-X \& Wilson EM 1996 a Reduced androgen receptor gene expression with first exon CAG repeat expansion. Molecular Endocrinology 10 1527-1535.

Choong CS, Quigley CA, French FS \& Wilson EM $1996 b$ A novel missense mutation in the amino-terminal domain of the human androgen receptor gene in a family with partial androgen insensitivity syndrome causes reduced efficiency of protein translation. Fournal of Clinical Investigation 98 1423-1431.

Choong CS, Kemppainen JA \& Wilson EM 1998 Evolution of the primate androgen receptor: a structural basis for disease. Fournal of Molecular Evolution 47 334-342.

Chung MY, Ranum LP, Duvick LA, Servadio A, Zoghbi HY \& Orr HT 1993 Evidence for a mechanism predisposing to 
intergenerational CAG repeat instability in spinocerebellar ataxia type I. Nature Genetics 5 254-258.

Craig-Holmes AP \& Shaw MW 1971 Polymorphism of human constitutive heterochromatin. Science 174 702-704.

Culig Z, Hobisch A, Cronauer MV, Cato AC, Hittmair A, Radmayr C, Eberle J, Bartsch G \& Klocker H 1993 Mutant androgen receptor detected in an advanced-stage prostatic carcinoma is activated by adrenal androgens and progesterone. Molecular Endocrinology 7 1541-1550.

Cunha GR, Donjacour AA, Cooke PS, Mee S, Bigsby RM, Higgins SJ \& Sugimura 1987 The endocrinology and the developmental biology of the prostate. Endocrine Reviews $\mathbf{8}$ 338-362.

Danek A, Witt TN, Mann K, Schweikert HU, Romalo G, La Spada AR \& Fischbeck KH 1994 Decrease in androgen binding and effect of androgen treatment in a case of $\mathrm{X}$-linked bulbospinal neuronopathy. Clinical Investigator 72 892-897.

Davies SW, Turmaine M, Cozens BA, Difiglia M, Sharp AH, Ross CA, Scherzinger E, Wanker EE, Mangiarini L \& Bates GP 1997 Formation of neuronal intranuclear inclusions underlies the neurological dysfunction in mice transgenic for the Hd mutation. Cell 90 537-548.

Davis BM, McCurrach ME, Taneja KI, Singer RH \& Housman DE 1997 Expansion of a CUG trinucleotide repeat in the $3^{\prime}$ untranslated region of myotonic dystrophy protein kinase transcripts results in nuclear retention of transcripts. Proceedings of the National Academy of Sciences of the USA 94 7388-7393.

De Bellis A, Quigley CA, Cariello NF, El-Awady MK, Sar M, Lane MV, Wilson EM \& French FS 1992 Single base mutations in the human androgen receptor gene causing complete androgen insensitivity: rapid detection by a modified denaturing gradient gel electrophoresis technique. Molecular Endocrinology 6 1909-1920.

Devys D, Lutz Y, Rouyer N, Bellocq JP \& Mandel JL 1993 The FMR-1 protein is cytoplasmic, most abundant in neurons and appears normal in carriers of a fragile $\mathrm{X}$ premutation. Nature Genetics 4 335-340.

DiFiglia M, Sapp E, Chase KO, Davies SW, Bates GP, Vonsattel JP \& Aronin N 1997 Aggregation of Huntingtin in neuronal intranuclear inclusions and dystrophic neurites in brain. Science 277 1990-1993.

Djian P, Hancock JM \& Chana HS 1996 Codon repeats in genes associated with human diseases: fewer repeats in the genes of nonhuman primates and nucleotide substitutions concentrated at the sites of reiteration. Proceedings of the National Academy of Sciences of the USA 93 417-421.

Doumit ME, Cook DR \& Merkel RA 1996 Testosterone up-regulates androgen receptors and decreases differentiation of porcine myogenic satellite cells in vitro. Endocrinology 137 1385-1394.

Doyu M, Sobue G, Kimata K, Yamamoto K \& Mitsuma T 1994 Androgen receptor mRNA with increased size of tandem CAG repeat is widely expressed in the neural and nonneural tissues of $\mathrm{X}$-linked recessive bulbospinal neuronopathy. Fournal of the Neurological Sciences 127 43-47.

Dragunow M, Faull RL, Lawlor P, Beilharz EJ, Singleton K, Walker EB \& Mee E 1995 In situ evidence for DNA fragmentation in Huntington's disease striatum and Alzheimer's disease temporal lobes. Neuroreport 6 1053-1057.

Dreyfuss G, Swanson MS \& Pinol-Roma S 1988 Heterogeneous nuclear ribonucleoprotein particles and the pathway of mRNA formation. Trends in Biochemical Sciences 13 86-91.

Duyao M, Ambrose C, Myers R, Novelletto A, Persichetti F, Frontali M, Folstein S, Ross C, Franz M, Abbott M, Gray
J, Conneally P, Young A, Penney J, Hollingsworth Z, Shoulson I, Lazzarini A, Falek A, Koroshetz W, Sax D, Bird E, Vonsattel J, Bonilla E, Alvir J, Bickham Conde J, Cha JH, Dure L, Gomez F, Ramos M, Sanchez-Ramos J, Snodgrass S, de Young M, Wexler N, Moscowitz C, Penchaszadeh G, MacFarlane H, Anderson M, Jenkins B, Srinidhi J, Barnes G, Gusella J \& MacDonald M 1993 Trinucleotide repeat length instability and age of onset in Huntington's disease. Nature Genetics 4 387-392.

Eagle LR, Yin X, Brothman AR, Williams BJ, Atkin NB \& Prochownik EV 1995 Mutation of the MXI1 gene in prostate cancer. Nature Genetics 9 249-255.

Edwards A, Hammond HA, Jin L, Caskey CT \& Chakraborty R 1992 Genetic variation at five trimeric and tetrameric tandem repeat loci in four human population groups. Genomics 12 241-253.

Evans RM 1988 The steroid and thyroid hormone receptor superfamily. Science 240 889-895.

Faber PW, Kuiper GGJM, van Rooij HCJ, van der Korput JAGM, Brinkmann AO \& Trapman J 1989 The N-terminal domain of the human androgen receptor is encoded by one large exon. Molecular and Cellular Endocrinology 61 257-262.

French FS, Lubahn DB, Brown TR, Simental JA, Quigley CA, Yarbrough WG, Tan JA, Sar M, Joseph DR, Evans BAJ, Hughes IA, Migeon CJ \& Wilson EM 1990 Molecular basis of androgen insensitivity. Recent Progress in Hormone Research 46 1-38.

Frydenberg M, Stricker P \& Kave KW 1997 Prostate cancer diagnosis and management. Lancet 349 1681-1687.

Gaddipati JP, McLeod DG, Heidenberg HB, Sesterhenn IA, Finger MJ, Moul JW \& Srivastava S 1994 Frequent detection of codon 877 mutation in the androgen receptor gene in advanced prostate cancers. Cancer Research $\mathbf{5 4}$ 2861-2864.

Gartler SM \& Riggs AD 1983 Mammalian X-chromosome inactivation. Annual Reviews in Genetics 17 155-190.

Gecz J, Gedeon AK, Sutherland GR \& Mulley JC 1996 Identification of the gene FMR2, associated with FRAXE mental retardation. Nature Genetics 13 105-108.

Gerber H-P, Seipel K, Georgiev O, Hofferrer M, Hug M, Rusconi S \& Schaffner W 1994 Transcriptional activation modulated by homopolymeric glutamine and proline stretches. Science 263 808-811.

Giovannucci E, Stampfer MJ, Krithivas K, Brown M, Brufsky A, Talcott J, Hennekens CH \& Kantoff PW 1997 The CAG repeat within the androgen receptor gene and its relationship to prostate cancer. Proceedings of the National Academy of Sciences of the USA 94 3320-3323.

Gittes RF 1991 Carcinoma of the prostate. New England Fournal of Medicine 324 236-245.

Godde JS \& Wolffe AP 1996 Nucleosome assembly on CTG triplet repeats. Fournal of Biological Chemistry 271 15222-15229.

Goldberg YP, Nicholson DW, Rasper DM, Kalchman MA, Koide HB, Graham RK, Bromm M, Kazemi-Esfarjani P, Thornberry NA, Vaillancourt JP \& Hayden MR 1996 Cleavage of huntingtin by apopain, a proapoptotic cysteine protease, is modulated by the polyglutamine tract. Nature Genetics 13 442-449.

Gottlieb B, Trifiro M, Lumbroso R \& Pinsky L 1997 The androgen receptor gene mutations database. Nucleic Acids Research 25 158-162.

Green H 1993 Human genetic diseases due to reiteration: relationship to an evolutionary mechanism. Cell 74 955-956.

Green S, Walter P, Kumar V, Krust A, Bornert JM, Argos P \& Chambon P 1986 Human oestrogen receptor cDNA; sequence, expression and homology to v-erb-A. Nature 320 $134-139$. 
Gu Y, Shen Y, Gibbs RA \& Nelson DL 1996 Identification of FMR2, a novel gene associated with the FRAXE CCG repeat and $\mathrm{CpG}$ island. Nature Genetics 13 109-113.

Hakimi JM, Schoenberg MP, Rondinelli RH, Piantadosi S \& Barrack ER 1997 Androgen receptor variants with short glutamine or glycine repeats may identify unique subpopulations of men with prostate cancer. Clinical Cancer Research 3 1599-1608.

Hamel BC, Smits AP, de Graaff E, Smeets DF, Schoute F, Eussen BH, Knight SJ, Davies KE, Assman-Hulsmans CF \& Oostra BA 1994 Segregation of FRAXE in a large family: clinical, psychometric, cytogenetic, and molecular data. American fournal of Human Genetics 55 923-931.

Hamshere MG, Newman EE, Alwazzan M, Athwal B \& Brook JD 1997 Transcriptional abnormality in myotonic dystrophy affects DMPK but not neighboring genes. Proceedings of the National Academy of Sciences of the USA 94 7394-7399.

Harding AE 1993 Clinical features and classification of inherited ataxias. Advances in Neurology 61 1-14.

Harding AE, Thomas PK, Baraitser M, Bradbury PG, Morgan-Hughes JA \& Ponsford JR 1982 X-linked recessive bulbospinal neuronopathy: a report of ten cases. Fournal of Neurology, Neurosurgery and Psychiatry 45 1012-1019.

Hardy DO, Scher HI, Bogenreider T, Sabbatini P, Zhang ZF, Nanus DM \& Catterall JF 1996 Androgen receptor CAG repeat lengths in prostate cancer: correlation with age of onset. Fournal of Clinical Endocrinology and Metabolism 81 4400-4405.

Harley HG, Rundle SA, MacMillan JC, Myring J, Brook JD, Crow S, Reardon W, Fenton I, Shaw DJ \& Harper PS 1993 Size of the unstable CTG repeat sequence in relation to phenotype and parental transmission in myotonic dystrophy. American fournal of Human Genetics 52 1164-1174.

Hayes RB, Liff JM, Pottern LM, Greenberg RS, Schoenberg JB, Schwartz AG, Swanson GM, Silverman DT, Brown LM, Hoover RN \& Fraumeni JF 1995 Prostate cancer risk in US blacks and whites with a family history of cancer. International Fournal of Cancer 60 361-364.

Hiort O, Wodtke A, Struve D, Zollner A \& Sinnecker GH 1994 Detection of point mutations in the androgen receptor gene using non-isotopic single strand conformation polymorphism analysis. German Collaborative Intersex Study Group. Human Molecular Genetics 3 1163-1166.

Hollenberg SM, Weinberger C, Ong ES, Cerelli G, Ord AE, Lebo R, Thompson EB, Rosenfeld MG \& Evans RM 1985 Primary structure and expression of a functional human glucocorticoid receptor cDNA. Nature 318 635-641.

Hoogeveen AT, Willemsen R, Meyer N, de Rooij KE, Roos RA, van Ommen GJ \& Galjaard H 1993 Characterization and localization of the Huntington disease gene product. Human Molecular Genetics 2 2069-2073.

Husmann DA, McPhaul MJ \& Wilson JD 1991 Androgen receptor expression in the developing rat prostate is not altered by castration, flutamide, or suppression of the adrenal axis. Endocrinology 128 1902-1906.

Igarashi S, Tanno Y, Onodera O, Yamazaki M, Sato S, Ishikawa A, Miyatani N, Nagashima M, Ishikawa Y, Sahashi K, Ibi T, Miyatake T \& Tsuji S 1992 Strong correlation between the number of CAG repeats in androgen receptor genes and the clinical onset of features of spinal and bulbar muscular atrophy. Neurology 42 2300-2302.

Ikeda H, Yamaguchi M, Sugai S, Aze Y, Narumiya S \& Kakizuka A 1996 Expanded polyglutamine in the MachadoJoseph disease protein induces cell death in vitro and in vivo. Nature Genetics 13 196-202.

Imagawa M, Ishikawa Y, Shimano H, Osada S \& Nishihara T 1995 CTG triplet repeat in mouse growth inhibitory factor/ metallothionein III gene promoter represses the transcriptional activity of the heterologous promoters. Fournal of Biological Chemistry 270 20898-20900.

Imbert G, Saudou F, Yvert G, Devys D, Trottier Y, Garnier JM, Weber C, Mandel JL, Cancel G, Abbas N, Durr A, Didierjean O, Stevanin G, Agid Y \& Brice A 1996 Cloning of the gene for spinocerebellar ataxia 2 reveals a locus with high sensitivity to expanded CAG/glutamine repeats. Nature Genetics 14 285-291.

Irvine RA, Yu MC, Ross RK \& Coetzee GA 1995 The CAG and GGC microsatellites of the androgen receptor gene are in linkage disequilibrium in men with prostate cancer. Cancer Research 55 1937-1940.

Jaworski A, Rosche WA, Gellibolian R, Kang S, Shimizu M, Bowater RP, Sinden RR \& Wells RD 1995 Mismatch repair in Escherichia coli enhances instability of $(\mathrm{CTG})_{\mathrm{n}}$ triplet repeats from human hereditary diseases. Proceedings of the National Academy of Sciences of the USA 92 11019-11023.

Jenster G, van der Korput HA, van Vroonhoven C, van der Kwast TH, Trapman J \& Brinkmann AO 1991 Domains of the human androgen receptor involved in steroid binding, transcriptional activation, and subcellular localization. Molecular Endocrinology 5 1396-1404.

Jenster G, de Ruiter PE, van der Korput HA, Kuiper GG, Trapman J \& Brinkmann AO 1994 Changes in the abundance of androgen receptor isotypes: effects of ligand treatment, glutamine-stretch variation, and mutation of putative phosphorylation sites. Biochemistry 33 14064-14072.

Jones C, Penny L, Mattina T, Yu S, Baker E, Voullaire L, Langdon WY, Sutherland GR, Richards RI \& Tunnacliffe A 1995 Association of a chromosome deletion syndrome with a fragile site within the proto-oncogene CBL2. Nature 376 145-149.

Jost A, Vigier B, Prepin J \& Perchellet JP 1973 Studies on sex differentiation in mammals. Recent Progress in Hormone Research 29 1-41.

Kalchman MA, Graham RK, Xia G, Koide HB, Hodgson JG, Graham KC, Goldberg YP, Gietz RD, Pickart CM \& Hayden MR 1996 Huntingtin is ubiquitinated and interacts with a specific ubiquitin-conjugating enzyme. Fournal of Biological Chemistry 271 19385-19394.

Kalchman MA, Koide HB, McCutcheon K, Graham RK, Nichol K, Nishiyama K, Kazemi-Esfarjani P, Lynn FC, Wellington C, Metzler M, Goldberg YP, Kanazawa I, Gietz RD \& Hayden MR 1997 HIP1, a human homologue of $S$. cerevisiae Sla2p, interacts with membrane-associated huntingtin in the brain. Nature Genetics 16 44-53.

Kang S, Jarworski A, Ohshima K \& Wells RD 1995 a Expansion and deletions of CTG repeats from human disease genes are determined by the direction of replication in E. coli. Nature Genetics 10 213-218.

Kang S, Ohshima K, Shimizu M, Amirhaeri S \& Wells RD $1995 b$ Pausing of DNA synthesis in vitro at specific loci in CTG and CGG triplet repeats from human hereditary disease genes. Fournal of Biological Chemistry 270 27014-27021.

Karlin S \& Burge C 1996 Trinucleotide repeats and long homopeptides in genes and proteins associated with nervous system disease and development. Proceedings of the National Academy of Sciences of the USA 93 1560-1565.

Kennedy WR, Alter M \& Sung JH 1968 Progressive proximal spinal and bulbar muscular atrophy of late onset. Neurology 18 671-680.

Kirshner MA \& Bardin CW 1972 Androgen production and metabolism in normal and virilized women. Metabolism 21 667-688.

Klockgether T, Kramer B, Ludtke R, Schols L \& Laccone F 1996 Repeat length and disease progression in spinocerebellar ataxia type 3. Lancet 348830 . 
Koide R, Ikeuchi T, Onodera O, Tanaka H, Igarashi S, Endo K, Takahashi H, Kondo R, Ishikawa A, Hayashi T, Saito M, Tomoda A, Miike T, Naito H, Ikuta F \& Tsuji S 1994 Unstable expansion of CAG repeat in hereditary dentatorubral-pallidoluysian atrophy (DRPLA). Nature Genetics 6 9-13.

Koivisto P, Kononen J, Palmberg C, Tammela T, Hyytinen E, Isola J, Trapman J, Cleutjens K, Noordzij A, Visakorpi T \& Kallioniemi OP 1997 Androgen receptor gene amplification: a possible molecular mechanism for androgen deprivation therapy failure in prostate cancer. Cancer Research $\mathbf{5 7}$ 314-319.

Koshy B, Matilla T, Burright EN, Merry DE, Fischbeck KH, Orr HT \& Zoghbi HY 1996 Spinocerebellar ataxia type-1 and spinobulbar muscular atrophy gene products interact with glyceraldehyde-3-phosphate dehydrogenase. Human Molecular Genetics 5 1311-1318.

Kremer B, Goldberg P, Andrew SE, Theilmann J, Telenius H, Zeisler J, Squitieri F, Lin B, Bassett A, Almqvist E, Bird TD \& Hayden MR 1994 A worldwide study of the Huntington's disease mutation. The sensitivity and specificity of measuring CAG repeats. New England Fournal of Medicine 330 1401-1406.

Kremer EJ, Pritchard M, Lynch M, Yu S, Holman K, Baker E, Warren ST, Schlessinger D, Sutherland GR \& Richards RI 1991 Mapping of DNA instability at the fragile X to a trinucleotide repeat sequence $\mathrm{p}(\mathrm{CCG}) \mathrm{n}$. Science $\mathbf{2 5 2}$ 1711-1714.

Kuiper GG, Faber PW, van Rooij HC, van der Korput JA, Ris-Stalpers C, Klaassen P, Trapman J \& Brinkmann AO 1989 Structural organization of the human androgen receptor gene. Fournal of Molecular Endocrinology 2 R1-R4.

Kunst CB \& Warren ST 1994 Cryptic and polar variation of the fragile $\mathrm{X}$ repeat could result in predisposing normal alleles. Cell 77 853-861.

Lalioti MD, Scott HS, Buresi C, Rossier C, Bottani A, Morris MA, Malafosse A \& Antonarakis SE 1997 Dodecamer repeat expansion in cystatin $\mathrm{B}$ gene in progressive myoclonus epilepsy. Nature 386 847-851.

Langley E, Zhou ZX \& Wilson EM 1995 Evidence for an anti-parallel orientation of the ligand-activated human androgen receptor dimer. Fournal of Biological Chemistry 270 29983-29990.

La Spada AR, Wilson EM, Lubahn DB, Harding AE \& Fischbeck KH 1991 Androgen receptor gene mutations in $\mathrm{X}$-linked spinal and bulbar muscular atrophy. Nature $\mathbf{3 5 2}$ 77-79.

La Spada AR, Roling DB, Harding AE, Warner CL, Spiegel R, Hausmanowa-Petrusewicz I, Yee WC \& Fischbeck KH 1992 Meiotic stability and genotype-phenotype correlation of the trinucleotide repeat in X-linked spinal and bulbar muscular atrophy. Nature Genetics 2 301-304.

La Spada AR, Peterson KR, Meadows SA, McClain ME, Jeng G, Chmelar RS, Haugen HA, Chen K, Singer MJ, Moore D, Trask BJ, Fischbeck KH, Clegg CH \& McKnight GS 1998 Androgen receptor YAC transgenic mice carrying CAG 45 alleles show trinucleotide repeat instability. Human Molecular Genetics 7 959-967.

Li XJ, Li SH, Sharp AH, Nucifora FC, Schilling G, Lanahan A, Worley P, Snyder SH \& Ross CA 1995 A huntingtinassociated protein enriched in brain with implications for pathology. Nature 378 398-402.

Lubahn DB, Joseph DR, Sar M, Tan J, Higgs HN, Larson RE, French FS \& Wilson EM 1988a The human androgen receptor: complementary deoxyribonucleic acid cloning, sequence analysis and gene expression in prostate. Molecular Endocrinology 2 1265-1275.
Lubahn DB, Joseph DR, Sullivan PM, Willard HF, French FS \& Wilson EM $1988 b$ Cloning of human androgen receptor complementary DNA and localization to the X chromosome. Science 240 327-330.

Lu-Yao GL \& Greenberg ER 1994 Changes in prostate cancer incidence and treatment in USA. Lancet 343 251-254.

Lyon MF 1972 X-chromosome inactivation and developmental patterns in mammals. Biological Reviews 47 1-35.

McLaughlin BA, Spencer C \& Eberwine J 1996 CAG trinucleotide RNA repeats interact with RNA-binding proteins. American Fournal of Human Genetics 59 561-569.

MacLean HE, Choi WT, Rekaris G, Warne GL \& Zajac JD $1995 a$ Abnormal androgen receptor binding affinity in subjects with Kennedy's disease (spinal and bulbar muscular atrophy). Fournal of Clinical Endocrinology and Metabolism 80 508-516.

MacLean HE, Chu S, Joske F, Warne GL \& Zajac JD $1995 b$ Androgen receptor binding studies on heterozygotes in a family with androgen insensitivity syndrome. Biochemical and Molecular Medicine 55 31-37.

MacMillan JC, Snell RG, Tyler A, Houlihan GD, Fenton I, Cheadle JP, Lazarou LP, Shaw DJ \& Harper PS 1993 Molecular analysis and clinical correlations of the Huntington's disease mutation. Lancet 342 954-958.

McPhaul MJ, Marcelli M, Zoppi S, Griffin JE \& Wilson JD 1993 Genetic basis of endocrine disease. 4. The spectrum of mutations in the androgen receptor gene that causes androgen resistance. Fournal of Clinical Endocrinology and Metabolism 76 17-23.

Mahadevan MS, Amemiya C, Jansen G, Sabourin L, Baird S, Neville CE, Wormskamp N, Segers B, Batzer M, Lamerdin J, de Jong P, Wieringa B \& Korneluk RG 1993 Structure and genomic sequence of the myotonic dystrophy (DM kinase) gene. Human Molecular Genetics 2 299-304.

Mangelsdorf DJ, Thummel C, Beato M, Herrlich P, Schutz G, Umesono K, Blumberg B, Kastner P, Mark M, Chambon P \& Evans RM 1995 The nuclear receptor superfamily: the second decade. Cell 83 835-839.

Mangiarini L, Sathasivam K, Seller M, Cozens B, Harper A, Hetherington C, Lawton M, Trottier Y, Lehrach H, Davies SW \& Bates GP 1996 Exon 1 of the HD gene with an expanded CAG repeat is sufficient to cause a progressive neurological phenotype in transgenic mice. Cell 87 493-506.

Matsuura T, Demura T, Aimoto Y, Mizuno T, Moriwaka F \& Tashiro K 1992 Androgen receptor abnormality in X-linked spinal and bulbar muscular atrophy. Neurology 42 1724-1726.

Mhatre AN, Trifiro MA, Kaufman M, Kazemi-Esfarjani P, Figlewicz D, Rouleau G \& Pinsky L 1993 Reduced transcriptional regulatory competence of the androgen receptor in X-linked spinal and bulbar muscular atrophy. Nature Genetics 5 184-188.

Misrahi M, Atger M, d'Auriol L, Loosfelt H, Meriel C, Fridlansky F, Guiochon-Mantel A, Galibert F \& Milgrom E 1987 Complete amino acid sequence of the human progesterone receptor deduced from cloned cDNA. Biochemical and Biophysical Research Communications 143 740-748.

Mitchell PJ \& Tjian R 1989 Transcriptional regulation in mammalian cells by sequence-specific DNA binding proteins. Science 245 371-378.

Miwa S 1994 Triplet repeats strike again. Nature Genetics 6 $3-4$.

Moorandian AD, Morley JE \& Koreman SG 1987 Biological actions of androgens. Endocrine Reviews 8 1-29.

Myers RH, Vonsattel JP, Paskevich PA, Kiely DK, Stevens TJ, Cupples LA, Richardson EP \& Bird ED 1991 Decreased neuronal and increased oligodendroglial densities in 
Huntington's disease caudate nucleus. Fournal of Neuropathology and Experimental Neurology 50 729-742.

Nadel Y, Weisman-Shomer P \& Fry M 1995 The fragile X syndrome single strand $\mathrm{d}(\mathrm{CGG}) \mathrm{n}$ nucleotide repeats readily fold back to form unimolecular hairpin structures. Fournal of Biological Chemistry 270 28970-28977.

Nagafuchi S, Yanagisawa H, Ohsaki E, Shirayama T, Tadokoro K, Inoue T \& Yamada M 1994a Structure and expression of the gene responsible for the triplet repeat disorder, dentatorubral and pallidoluysian atrophy (DRPLA). Nature Genetics 8 177-182.

Nagafuchi S, Yanagisawa H, Sato K, Shirayama T, Ohsaki E, Bundo M, Takeda T, Tadokoro K, Kondo I, Murayama N, Tanaka Y, Kikushima H, Umino K, Kurosawa H, Furukawa T, Nihei K, Inoue T, Sano A, Komure D, Takahashi M, Yoshizawa T, Kanazawa I \& Yamada M $1994 b$ Dentatorubral and pallidoluysian atrophy expansion of an unstable CAG trinucleotide on chromosome 12p. Nature Genetics 6 14-18.

Nahoul K \& Roger M 1990 Age-related decline in plasma bioavailable testosterone in adult men. Fournal of Steroid Biochemistry 35 293-299.

Nakamura M, Mita S, Murakami T, Uchino M, Watanabe S, Tokunaga M, Kumamoto T \& Ando M 1994 Exonic trinucleotide repeats and expression of androgen receptor gene in spinal cord from X-linked spinal and bulbar muscular atrophy. Fournal of the Neurological Sciences 122 74-79.

Narod SA, Dupont A, Cusan L, Diamond P, Gomez JL, Suburu R \& Labrie F 1995 The impact of family history on early detection of prostate cancer. Nature Medicine 1 99-101.

Newmark JR, Hardy DO, Tonb DC, Carter BS, Epstein JI, Isaacs WB, Brown TR \& Barrack ER 1992 Androgen receptor gene mutations in human prostate cancer. Proceedings of the National Academy of Sciences of the USA 89 6319-6323.

Ohshima K, Kang S, Larson JE \& Wells RD 1996 Cloning, characterization, and properties of seven triplet repeat DNA sequences. Fournal of Biological Chemistry 271 16773-16783.

Onodera O, Oyake M, Takano H, Ikeuchi T, Igarashi S \& Tsuji S 1995 Molecular cloning of a full-length cDNA for dentatorubral-pallidoluysian atrophy and regional expressions of the expanded alleles in the CNS. American fournal of Human Genetics 57 1050-1060.

Ordway JM, Tallaksen-Greene S, Gutekunst C-A, Bernstein EM, Cearley JA, Weiner HW, Dure IV LS, Lindsey R, Hersch SM, Jope RS, Albin RL \& Detloff PJ 1997 Ectopically expressed CAG repeats cause intranuclear inclusions and a progressive late onset neurological phenotype in the mouse. Cell 91 753-763.

Orr HT, Chung M-Y, Banfi S, Kwiatkowski TJ, Servadio A, Beaudet AL, McCall AE, Duvick LA, Ranum LPW \& Zoghbi HY 1993 Expansion of an unstable trinucleotide CAG repeat in spinocerebellar ataxia type 1. Nature Genetics 4 221-226.

Patterson MN, McPhaul MJ \& Hughes IA 1994 Androgen insensitivity syndrome. Baillieres Clinical Endocrinology and Metabolism 8 379-404.

Paulson HL \& Fischbeck KH 1996 Trinucleotide repeats in neurogenetic disorders. Annual Reviews in Neuroscience 19 79-107.

Pennachio LA, Lehesjoki A-E, Stone N, Willour VL, Virtneva K, Miao J, D'Amato E, Ramirez L, Faham M, Koskiniemi M, Warrington JA, Norio R, de La Chapelle A, Cox DR \& Myers RM 1996 Mutations in the gene encoding cystatin B in progressive myoclonus epilepsy. Science 271 1731-1733.

Perutz MF, Johnson T, Suzuki M \& Finch JT 1994 Glutamine repeats as polar zippers: their possible role in inherited neurodegenerative diseases. Proceedings of the National Academy of Sciences of the USA 91 5355-5358.

Pieretti M, Zhang F, Fu YH, Warren ST, Oostra BA, Caskey CT \& Nelson DL 1991 Absence of expression of the FMR-1 gene in fragile X syndrome. Cell 66 817-822.

Portera-Cailliau C, Hedreen JC, Price DL \& Koliatsos VE 1995 Evidence for apoptotic cell death in Huntington's disease and excitotoxic animal models. Fournal of Neuroscience 15 3775-3787.

Pulst SM, Nechiporuk A, Nechiporuk T, Gispert S, Chen XN, Lopes-Cendes I, Pearlman S, Starkman S, Orozco-Diaz G, Lunkes A, DeJong P, Rouleau GA, Auburger G, Korenberg JR, Figueroa C \& Sahba S 1996 Moderate expansion of a normally biallelic trinucleotide repeat in spinocerebellar ataxia type 2. Nature Genetics 14 269-276.

Quigley CA, De Bellis A, Marschke KB, El-Awady MK, Wilson EM \& French FS 1995 Androgen receptor defects: historical, clinical, and molecular perspectives. Endocrine Reviews 16 271-321.

Ranum LPW, Chung MY, Banfi S, Bryer A, Schut LJ, Ramesar R, Duvick LA, McCall A, Subramony SH, Goldfarb L, Gomez C, Sandkuijl LA, Orr HT \& Zoghbi HY 1994 Molecular and clinical correlations in spinocerebellar ataxia type I: evidence for familial effects on the age at onset. American Fournal of Human Genetics 55 244-252.

Richards RI \& Sutherland GR 1994 Simple repeat DNA is not replicated simply. Nature Genetics 6 114-116.

Richards RI, Crawford J, Narahara K, Mangelsdorf M, Friend K, Staples A, Denton M, Easteal S, Hori TA, Kondo I, Jenkins T, Goldman A, Panich V, Ferakova E \& Sutherland GR 1996 Dynamic mutation loci: allele distributions in different populations. Annals of Human Genetics $\mathbf{6 0}$ 391-400.

Roehrborn CG, Lange JL, George FW \& Wilson JD 1987 Changes in amount and intracellular distribution of androgen receptor in human foreskin as a function of age. Fournal of Clinical Investigation 79 44-47.

Roses AD 1996 From genes to mechanisms to therapies: lessons to be learned from neurological disorders. Nature Medicine 2 267-269.

Rosner W 1991 Plasma steroid-binding proteins. Endocrinology Metabolism Clinics North America $20697-720$.

Rubinsztein DC, Amos W, Leggo J, Goodburn S, Jain S, Li SH, Margolis RL \& Ross CA 1995a Microsatellite evolution evidence for directionality and variation in rate between species. Nature Genetics 10 337-343.

Rubinsztein DC, Leggo J, Coetzee GA, Irvine RA, Buckley M \& Ferguson-Smith MA $1995 b$ Sequence variation and size ranges of CAG repeats in the Machado-Joseph disease, spinocerebellar ataxia type 1 and androgen receptor genes. Human Molecular Genetics 4 1585-1590.

Rubinsztein DC, Leggo J, Goodburn S, Barton DE \& Ferguson-Smith MA $1995 c$ Haplotype analysis of the $\Delta 2642$ and $(\mathrm{CAG})_{\mathrm{n}}$ polymorphisms in the Huntington's disease (HD) gene provides an explanation for an apparent 'founder' HD haplotype. Human Molecular Genetics 4 203-206.

Ruizeveld de Winter JA, Trapman J, Vermey M, Mulder E, Zegers ND \& van der Kwast TH 1991 Androgen receptor expression in human tissues: an immunohistochemical study. Fournal of Histochemistry and Cytochemistry 39 927-936.

Rundlett SE, Wu XP \& Miesfeld RL 1990 Functional characterizations of the androgen receptor confirm that the molecular basis of androgen action is transcriptional regulation. Molecular Endocrinology 4 708-714.

Sar M, Lubahn DB, French FS \& Wilson EM 1990 Immunohistochemical localization of the androgen receptor in rat and human tissues. Endocrinology 127 3180-3186. 
Sawyer R, Berman JJ, Borkowski A \& Moore GW 1996 Prostate-specific antigen in black men (letter). Lancet 347 1329.

Sawyer R, Berman JJ \& Moore GW 1997 Prostate-specific antigen in black men. New England Fournal of Medicine 336 133-134; discussion 135-136.

Scherzinger E, Lurz R, Turmaine M, Mangiarini L, Hollenbach B, Hasenbank R, Bates GP, Davies SW, Lehrach H \& Wanker EE 1997 Huntingtin-encoded polyglutamine expansions form amyloid-like protein aggregates in vitro and in vivo. Cell 90 549-558.

Schoenberg MP, Hakimi JM, Wang S, Bova GS, Epstein JI, Fischbeck KH, Isaacs WB, Walsh PC \& Barrack ER 1994 Microsatellite mutation (CAG24(18)) in the androgen receptor gene in human prostate cancer. Biochemical and Biophysical Research Communications 198 74-80.

Servadio A, Koshy B, Armstrong D, Antalffy B, Orr HT \& Zoghbi HY 1995 Expression analysis of the ataxin-1 protein in tissues from normal and spinocerebellar ataxia type 1 individuals. Nature Genetics 10 94-98.

Shimada N, Sobue G, Doyu M, Yamamoto K, Yasuda T, Mukai E, Kachi T \& Mitsuma T 1995 X-linked recessive bulbospinal neuronopathy: clinical phenotypes and CAG repeat size in androgen receptor gene. Muscle and Nerve $\mathbf{1 8}$ $1378-1384$

Sinclair AH, Berta P, Palmer MS, Hawkins JR, Griffiths BL, Smith MJ, Foster JW, Frischauf AM, Lovell-Badge R \& Goodfellow PN 1990 A gene from the human sexdetermining region encodes a protein with homology to a conserved DNA-binding motif. Nature 346 240-244.

Sleddens HFBM, Oostra BA, Brinkmann AO \& Trapman J 1993 Trinucleotide (GGN) repeat polymorphism in the human androgen receptor (AR) gene. Human Molecular Genetics 2493.

Snell RG, MacMillan JC, Cheadle JP, Fenton I, Lazarou LP, Davies P, MacDonald ME, Gusella JF, Harper PS \& Shaw DJ 1993 Relationship between trinucleotide repeat expansion and phenotypic variation in Huntington's disease. Nature Genetics 4 393-397.

Sobue G, Doyu M, Kachi T, Yasuda T, Mukai E, Kumagai T \& Mitsuma T 1993 Subclinical phenotypic expressions in heterozygous females of $\mathrm{X}$-linked recessive bulbospinal neuronopathy. Fournal of the Neurological Sciences $\mathbf{1 1 7}$ 74-78.

Sobue G, Doyu M, Morishima T, Mukai E, Yasuda T, Kachi $\mathrm{T} \&$ Mitsuma T 1994 Aberrant androgen action and increased size of tandem CAG repeat in androgen receptor gene in X-linked recessive bulbospinal neuronopathy. Fournal of the Neurological Sciences 121 167-171.

Stanford JL, Just JJ, Gibbs M, Wicklund KG, Neal CL, Blumenstein BA \& Ostrander EA 1997 Polymorphic repeats in the androgen receptor gene: molecular markers of prostate cancer risk. Cancer Research 57 1194-1198.

Strand M, Prolla TA, Liskay RM \& Petes TD 1993 Destabilization of tracts of simple repetitive DNA in yeast by mutations affecting DNA mismatch repair. Nature 365 $274-276$.

Strong TV, Tagle DA, Valdes JM, Elmer LW, Boehm K, Swaroop M, Kaatz KW, Collins FS \& Albin RL 1993 Widespread expression of the human and rat Huntington's disease gene in brain and nonneural tissues. Nature Genetics 5 259-265.

Sultan C, Lumbroso S, Poujol N, Belon C, Boudon C \& Lobaccaro JM 1993 Mutations of androgen receptor gene in androgen insensitivity syndromes. Fournal of Steroid Biochemistry and Molecular Biology 46 519-530.

Sutherland GR \& Richards RI 1993 Dynamic mutations on the move. Fournal of Medical Genetics 30 978-981.
Sutherland GR \& Richards RI 1995 Simple tandem DNA repeats and human genetic disease. Proceedings of the National Academy of Sciences of the USA 92 3636-3641.

Suzuki H, Komiya A, Aida S, Akimoto S, Shiraishi T, Yatani R, Igarashi T \& Shimazaki J 1995 Microsatellite instability and other molecular abnormalities in human prostate cancer. Fapanese Fournal of Cancer Research 86 956-961.

Suzuki H, Akakura K, Komiya A, Aida S, Akimoto S \& Shimazaki J 1996 Codon 877 mutation in the androgen receptor gene in advanced prostate cancer: relation to antiandrogen withdrawal syndrome. Prostate 29 153-158.

Takeda H, Chodak G, Mutchnik S, Nakamoto T \& Chang C 1990 Immunohistochemical localization of androgen receptors with mono- and polyclonal antibodies to androgen receptor. Fournal of Endocrinology 126 17-25.

Taplin ME, Bubley GJ, Shuster TD, Frantz ME, Spooner AE, Ogata GK, Keer HN \& Balk SP 1995 Mutation of the androgen-receptor gene in metastatic androgen-independent prostate cancer. New England Fournal of Medicine 332 1393-1398.

Thigpen AE, Davis DL, Milatovich A, Mendonca BB, Imperato-McGinley J, Griffin JE, Francke U, Wilson JD \& Russell DW 1992 Molecular genetics of steroid $5 \alpha$-reductase 2 deficiency. Fournal of Clinical Investigation 90 799-809.

Tilley WD, Marcelli M, Wilson JD \& McPhaul MJ 1989 Characterization and expression of a cDNA encoding the human androgen receptor. Proceedings of the National Academy of Sciences of the USA 86 327-331.

Tilley WD, Buchanan G, Hickey TE \& Bentel JM 1996 Mutations in the androgen receptor gene are associated with progression of human prostate cancer to androgen independence. Clinical Cancer Research 2 277-285.

Trifiro MA, Kazemi-Esfarjani P \& Pinsky L 1994 X-linked muscular atrophy and the androgen receptor. Trends in Endocrinology and Metabolism 5 416-421.

Tut TG, Ghadessy FJ, Trifiro MA, Pinsky L \& Yong EL 1997 Long polyglutamine tracts in the androgen receptor are associated with reduced trans-activation, impaired sperm production, and male infertility. Fournal of Clinical Endocrinology and Metabolism 82 3777-3782.

Veldscholte J, Ris-Stalpers C, Kuiper GG, Jenster G, Berrevoets C, Claassen E, van Rooij HC, Trapman J, Brinkmann AO \& Mulder E 1990 A mutation in the ligand binding domain of the androgen receptor of human $\mathrm{LNCaP}$ cells affects steroid binding characteristics and response to anti-androgens. Biochemical and Biophysical Research Communications 173 534-540.

Visakorpi T, Hyytinen E, Koivisto P, Tanner M, Keinanen R, Palmberg C, Palotie A, Tammela T, Isola J \& Kallioniemi OP 1995 In vivo amplification of the androgen receptor gene and progression of human prostate cancer. Nature Genetics 9 401-406.

Vonsattel JP, Myers RH, Stevens TJ, Ferrante RJ, Bird ED \& Richardson EP 1985 Neuropathological classification of Huntington's disease. Fournal of Neuropathology and Experimental Neurology 44 559-577.

Wang YH, Amirhaeri S, Kang S, Wells RD \& Griffith JD 1994 Preferential nucleosome assembly at DNA triplet repeats from the myotonic dystrophy gene. Science $\mathbf{2 6 5}$ 669-671.

Wanker EE, Rovira C, Scherzinger E, Hasenbank R, Walter S, Tait D, Colicelli J \& Lehrach H 1997 Hip-I - a huntingtin interacting protein isolated by the yeast two-hybrid system. Human Molecular Genetics 6 487-495.

Warner CL, Griffin JE, Wilson JD, Jacobs LD, Murray KR, Fischbeck KH, Dickoff D \& Griggs RC 1992 X-linked spinomuscular atrophy: a kindred with associated abnormal androgen receptor binding. Neurology 42 2181-2184. 
Weber JL 1990 Informativeness of human (dC-dA)n.(dG-dT)n polymorphisms. Genomics 7 524-530.

Wells RD 1996 Molecular basis of genetic instability of triplet repeats. Fournal of Biological Chemistry 271 2875-2878.

Whittemore AS, Wu AH, Kolonel LN, John EM, Gallagher RP, Howe GR, West DW, Teh CZ \& Stamey T 1995 Family history and prostate cancer risk in black, white, and Asian men in the United States and Canada. American Fournal of Epidemiology 141 732-740.

Wilson JD, Aiman J \& MacDonald PC 1980 The pathogenesis of gynecomastia. Advances in Internal Medicine 25 1-32.

Yamamoto KR 1985 Steroid receptor regulated transcription of specific genes and gene networks. Annual Review of Genetics 19 209-252.

Yazawa I, Nukina N, Hashida H, Goto J, Yamada M \& Kanazawa I 1995 Abnormal gene product identified in hereditary dentatorubral-pallidoluysian atrophy (DRPLA) brain. Nature Genetics 10 99-103.

Yeh S \& Chang C 1996 Cloning and characterization of a specific coactivator, ARA70, for the androgen receptor in human prostate cells. Proceedings of the National Academy of Sciences of the USA 93 5517-5521.

Zhou ZX, Sar M, French FS \& Wilson EM 1993 Molecular biological aspects of the human androgen receptor relating to disease. In Steroid Hormone Receptors, pp 407-426. Ed VK Moudgil. Boston: Birkhauser.
Zhou ZX, Wong CI, Sar M \& Wilson EM 1994 The androgen receptor: an overview. Recent Progress in Hormone Research 49 249-274.

Zhou ZX, Lane MV, Kemppainen JA, French FS \& Wilson EM 1995 Specificity of ligand-dependent androgen receptor stabilization: receptor domain interactions influence ligand dissociation and receptor stability. Molecular Endocrinology 9 208-218.

Zhuchenko O, Bailey J, Bonnen P, Ashizawa T, Stockton DW, Amos C, Dobyns WB, Subramony SH, Zoghbi HY \& Lee CC 1997 Autosomal dominant cerebellar ataxia (SCA6) associated with small polyglutamine expansions in the alpha 1A-voltage-dependent calcium channel. Nature Genetics 15 62-69.

Zoppi S, Wilson CM, Harbison MD, Griffin JE, Wilson JD, McPhaul MJ \& Marcelli M 1993 Complete testicular feminization caused by an amino-terminal truncation of the androgen receptor with downstream initiation. Fournal of Clinical Investigation 91 1105-1112.

Zumoff B, Strain GW, Kream J, O'Connor J, Rosenfeld RS, Levin J \& Fukushima DK 1982 Age variation of the 24-h mean plasma concentrations of androgens, estrogens, and gonadotropins in normal adult men. Fournal of Clinical Endocrinology and Metabolism 54 534-538.

RECEIVED 6 April 1998 